\title{
Atmospheric OH reactivities in the Pearl River Delta - China in summer 2006: measurement and model results
}

\author{
S. Lou ${ }^{1,2}$, F. Holland ${ }^{2}$, F. Rohrer ${ }^{2}$, K. Lu ${ }^{3,2}$, B. Bohn ${ }^{2}$, T. Brauers ${ }^{2}$, C.C. Chang ${ }^{6}$, H. Fuchs ${ }^{2}$, R. Häseler ${ }^{2}$, K. Kita ${ }^{4}$,

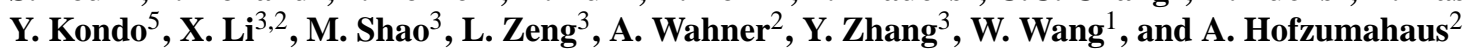 \\ ${ }^{1}$ School of Environmental Science and Technology, Shanghai Jiao Tong University, Shanghai, China \\ ${ }^{2}$ Institut für Energie und Klimaforschung: Troposphäre, Forschungszentrum Jülich, Jülich, Germany \\ ${ }^{3}$ College of Environmental Sciences and Engineering, Peking University, Beijing, China \\ ${ }^{4}$ Faculty of Science, Ibaraki University, Ibaraki, Japan \\ ${ }^{5}$ Research Center for Advanced Science and Technology, University of Tokyo, Tokyo, Japan \\ ${ }^{6}$ Research Center for Environmental Changes (RCEC), Academic Sinica, Taipei, China
}

Received: 4 August 2009 - Published in Atmos. Chem. Phys. Discuss.: 12 August 2009

Revised: 5 November 2010 - Accepted: 10 November 2010 - Published: 30 November 2010

\begin{abstract}
Total atmospheric $\mathrm{OH}$ reactivities $\left(k_{\mathrm{OH}}\right)$ have been measured as reciprocal $\mathrm{OH}$ lifetimes by a newly developed instrument at a rural site in the densely populated Pearl River Delta (PRD) in Southern China in summer 2006. The deployed technique, LP-LIF, uses laser flash photolysis (LP) for artificial $\mathrm{OH}$ generation and laser-induced fluorescence (LIF) to measure the time-dependent $\mathrm{OH}$ decay in samples of ambient air. The reactivities observed at PRD covered a range from $10 \mathrm{~s}^{-1}$ to $120 \mathrm{~s}^{-1}$, indicating a large load of chemical reactants. On average, $k_{\mathrm{OH}}$ exhibited a pronounced diurnal profile with a mean maximum value of $50 \mathrm{~s}^{-1}$ at daybreak and a mean minimum value of $20 \mathrm{~s}^{-1}$ at noon. The comparison of reactivities calculated from measured trace gases with measured $k_{\mathrm{OH}}$ reveals a missing reactivity of about a factor of 2 at day and night. The reactivity explained by measured trace gases was dominated by anthropogenic pollutants (e.g., $\mathrm{CO}, \mathrm{NO}_{\mathrm{x}}$, light alkenes and aromatic hydrocarbons) at night, while it was strongly influenced by local, biogenic emissions of isoprene during the day. Box model calculations initialized by measured parameters reproduce the observed $\mathrm{OH}$ reactivity well and suggest that the missing reactivity is contributed by unmeasured, secondary chemistry products (mainly aldehydes and ketones) that were photochemically formed by hydrocarbon oxidation. Overall, $k_{\mathrm{OH}}$ was dominated by organic compounds, which had a maximum contribution of $85 \%$ in the afternoon. The paper demonstrates the usefulness of direct reactivity measurements, emphasizes the
\end{abstract}

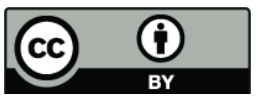

Correspondence to: A. Hofzumahaus (a.hofzumahaus@fz-juelich.de) need for direct measurements of oxygenated organic compounds in atmospheric chemistry studies, and discusses uncertainties of the modelling of OVOC reactivities.

\section{Introduction}

The hydroxyl radical $(\mathrm{OH})$ is the primary oxidant in the troposphere. It reacts with most atmospheric trace gases and, thereby, controls their rates of removal from the atmosphere (Ehhalt, 1999). In many cases, oxidation of primary pollutants by $\mathrm{OH}$ leads to formation of hydroperoxy $\left(\mathrm{HO}_{2}\right)$ and organic peroxy radicals $\left(\mathrm{RO}_{2}, \mathrm{R}=\right.$ organic group $)$ which are important intermediates in the photochemical formation of ozone and organic aerosols. A good understanding of tropospheric $\mathrm{OH}$ and its related chemistry is therefore indispensable for reliable prediction of the atmospheric selfcleansing and the formation of secondary atmospheric pollutants (Brasseur et al., 2003).

Tropospheric $\mathrm{OH}$ is produced primarily by a few relatively well-known processes, of which the UV photolysis of ozone is the most important one (Matsumi et al., 2002).

$\mathrm{O}_{3}+h v(\lambda<340 \mathrm{~nm}) \rightarrow \mathrm{O}\left({ }^{1} \mathrm{D}\right)+\mathrm{O}_{2}\left({ }^{1} \Delta,{ }^{3} \Sigma\right)$

$\mathrm{O}\left({ }^{1} \mathrm{D}\right)+\mathrm{H}_{2} \mathrm{O} \rightarrow \mathrm{OH}+\mathrm{OH}$

Other relevant processes include the photolysis of nitrous acid and ozonolysis of alkenes.

$\mathrm{OH}$ exhibits a high reactivity to many atmospheric trace components such as carbon monoxide $(\mathrm{CO})$, nitrogen oxides $\left(\mathrm{NO}, \mathrm{NO}_{2}\right)$ and volatile organic compounds (VOCs). $\mathrm{OH}$

Published by Copernicus Publications on behalf of the European Geosciences Union. 
reactions with $\mathrm{CO}$ and hydrocarbons $(\mathrm{RH})$ produce peroxy radicals $\left(\mathrm{HO}_{2}, \mathrm{RO}_{2}\right)$.

$$
\begin{aligned}
& \mathrm{CO}+\mathrm{OH} \rightarrow \mathrm{H}+\mathrm{CO}_{2} \\
& \mathrm{H}+\mathrm{O}_{2}+\mathrm{M} \rightarrow \mathrm{HO}_{2}+\mathrm{M} \\
& \mathrm{RH}+\mathrm{OH} \rightarrow \mathrm{R}+\mathrm{H}_{2} \mathrm{O} \\
& \mathrm{R}+\mathrm{O}_{2}+\mathrm{M} \rightarrow \mathrm{RO}_{2}+\mathrm{M}
\end{aligned}
$$

Subsequent reactions of $\mathrm{RO}_{2}$ and $\mathrm{HO}_{2}$ with $\mathrm{NO}$ recycle $\mathrm{OH}$.

$$
\begin{aligned}
& \mathrm{RO}_{2}+\mathrm{NO} \rightarrow \mathrm{RO}+\mathrm{NO}_{2} \\
& \mathrm{RO}+\mathrm{O}_{2} \rightarrow \mathrm{R}^{\prime} \mathrm{O}+\mathrm{HO}_{2} \\
& \mathrm{HO}_{2}+\mathrm{NO} \rightarrow \mathrm{OH}+\mathrm{NO}_{2} .
\end{aligned}
$$

Here, RO represents short-lived alkoxy radicals and $\mathrm{R}^{\prime} \mathrm{O}$ indicates carbonyl compounds (aldehydes, ketones).

$\mathrm{OH}$ loss can also occur by recombination reactions, which ultimately remove radicals from the atmosphere. In this class of reactions, association between $\mathrm{OH}$ and $\mathrm{NO}_{2}$ is the most important example.

$\mathrm{OH}+\mathrm{NO}_{2}+\mathrm{M} \rightarrow \mathrm{HNO}_{3}+\mathrm{M}$

Atmospheric $\mathrm{OH}$ is short-lived $(<1 \mathrm{~s})$ reaching a steady state of production and loss within a few seconds.

$$
\frac{d[\mathrm{OH}]}{d t}=P_{\mathrm{OH}}-k_{\mathrm{OH}}[\mathrm{OH}] \simeq 0
$$

In this equation, $P_{\mathrm{OH}}$ is the total production rate of $\mathrm{OH}$ from primary production (e.g., R2) and radical recycling reactions (e.g., R9), while $k_{\mathrm{OH}}$ represents the pseudo first-order rate coefficient of $\mathrm{OH}$ in ambient air. $k_{\mathrm{OH}}$ is also called total $\mathrm{OH}$ reactivity and is equivalent to the reciprocal atmospheric $\mathrm{OH}$ lifetime, $\tau_{\mathrm{OH}}^{-1}$.

$k_{\mathrm{OH}}=\sum k_{\mathrm{OH}+\mathrm{Xi}}\left[\mathrm{X}_{\mathrm{i}}\right]=\tau_{\mathrm{OH}}^{-1}$

Here, $\left[X_{i}\right]$ represents the concentration of a reactive component $\left(\mathrm{CO}, \mathrm{NO}_{\mathrm{x}}\right.$, VOCs etc. $)$ in ambient air, $k_{\mathrm{OH}+\mathrm{Xi}}$ denotes the corresponding bimolecular reaction rate constant and $k_{\mathrm{OH}+\mathrm{Xi}}\left[\mathrm{X}_{\mathrm{i}}\right]$ the reactivity of $\mathrm{X}_{\mathrm{i}}$.

A major uncertainty in atmospheric chemistry results from the incomplete knowledge of the number and abundance of reactive components that are present in the atmosphere. Besides well-known pollutants like $\mathrm{CO}$ and $\mathrm{NO}_{\mathrm{x}}$, a large number of probably more than $10^{5}$ different VOCs exists in the troposphere (Goldstein and Galbally, 2007), but less than one hundred VOCs are measured routinely in field campaigns. The measured VOC species are thought to represent the major organic reactivity. Recent field experiments, however, demonstrate that a considerable fraction of organic components missed by current measurement techniques may have significant influence on atmospheric photochemistry (Lewis et al., 2000; Di Carlo et al., 2004; Sadanaga et al., 2005; Holzinger et al., 2005; Goldstein and Galbally, 2007; Heald et al., 2008; Mao et al., 2009a). Thus, incomplete VOC measurements and unknown atmospheric components can introduce considerable uncertainty in model predictions, for example, of atmospheric OH (Poppe et al., 1994; McKeen et al., 1997).

A step towards solving this problem was made by the development of perturbation techniques that introduce artificially generated $\mathrm{OH}$ into samples of ambient air and measure directly the total $\mathrm{OH}$ reactivity. Some field instruments measure $k_{\mathrm{OH}}$ as the inverse of the atmospheric $\mathrm{OH}$ lifetime, either in a reaction flow tube with a movable $\mathrm{OH}$ injector (Kovacs and Brune, 2001; Mao et al., 2009a; Ingham et al., 2009) or by using a laser pump and probe technique (Calpini et al., 1999; Sadanaga et al., 2004b; Hofzumahaus et al., 2009). Another concept involves the comparative $k_{\mathrm{OH}}$ measurement in a flow cell against the known $\mathrm{OH}$ reactivity of an added organic reagent (Sinha et al., 2008). Using these various techniques, $k_{\mathrm{OH}}$ values have been observed between $1 \mathrm{~s}^{-1}$ in clean air and $200 \mathrm{~s}^{-1}$ in extremely polluted air in the atmospheric boundary layer (Table 1).

Measurements of $k_{\mathrm{OH}}$ provide valuable information and can be useful in atmospheric chemistry studies in different ways. First, experimental $k_{\mathrm{OH}}$ data provide the chemical reactivity that would be expected by calculation from individual trace gas measurements $\left(k_{\mathrm{OH}}^{\mathrm{calc}}\right)$, if all atmospheric $\mathrm{OH}$ reactants are completely measured and if each contribution $k_{\mathrm{OH}+\mathrm{Xi}}\left[\mathrm{X}_{\mathrm{i}}\right]$ is correctly determined. The ratio $k_{\mathrm{OH}} / k_{\mathrm{OH}}^{\text {calc }}$ allows quantification of the amount of reactivity that remains unmeasured or unidentified in field experiments. Missing reactivity has been reported for different environments, including marine, rural and urban sites, with measured-tocalculated reactivity ratios as high as 3 (Table 1).

Second, $k_{\mathrm{OH}}$ data can be used to estimate the atmospheric VOC reactivity, if measured data of non-VOC compounds $\left(\mathrm{Y}_{\mathrm{i}}=\mathrm{CO}, \mathrm{NO}_{\mathrm{x}}\right.$ etc. $)$ are simultaneously available:

$k_{\mathrm{OH}}(\mathrm{VOC}) \simeq k_{\mathrm{OH}}-\sum k_{\mathrm{OH}+\mathrm{Yi}}\left[\mathrm{Y}_{\mathrm{i}}\right]$

Shirley et al. (2006) and Ren et al. (2005, 2006b) have used such $k_{\mathrm{OH}}(\mathrm{VOC})$ data together with typical VOC speciation patterns as constraints for model predictions of $\mathrm{OH}$, when direct VOC measurements were not completely available.

Third, $\mathrm{OH}$ reactivity measurements are useful to evaluate experimentally the chemical $\mathrm{OH}$ budget (Martinez et al., 2003; Ren et al., 2003b; Shirley et al., 2006; Hofzumahaus et al., 2009). Possible unidentified $\mathrm{OH}$ production processes can be quantified by comparison of the experimental $\mathrm{OH}$ loss rate, $k_{\mathrm{OH}} \times[\mathrm{OH}]$, calculated from measured $\mathrm{OH}$ and $k_{\mathrm{OH}}$, with $P_{\mathrm{OH}}$ data derived from measured $\mathrm{OH}$ precursors. Such a study was carried out by Hofzumahaus et al. (2009) for data from a field campaign in the Pearl River Delta (PRD) in China in summer 2006. By comparing the total $\mathrm{OH}$ loss and 
Table 1. OH reactivities measured in the atmospheric boundary layer.

\begin{tabular}{|c|c|c|c|c|c|c|c|}
\hline Campaign & Site & Months, Year & Conditions & $k_{\mathrm{OH}}\left(\mathrm{s}^{-1}\right)^{\mathrm{a}}$ & $\mathrm{MR}^{\mathrm{b}}$ & $\begin{array}{l}\text { Measured } \\
\text { Species }^{c}\end{array}$ & Reference \\
\hline TORCH-2 & $\begin{array}{l}\text { Weybourne, } \\
\text { Norfolk, UK }\end{array}$ & Apr-May 2004 & Marine, Coast & $2-10$ & $\lesssim 3$ & SFO & Ingham et al. (2009) \\
\hline INTEX-B & Pacific Ocean & Apr-May 2006 & $\begin{array}{l}\text { Marine, } \\
\mathrm{h}=0-2 \mathrm{~km}^{\mathrm{e}}\end{array}$ & $4.0 \pm 1.0^{\mathrm{d}}$ & 2.5 & SFO & Mao et al. (2009a) \\
\hline PMTACS & New York, US & Jun-Aug 2001 & Megacity & $15-25$ & $\sim 1$ & SFO & Ren et al. (2003a) \\
\hline- & Tokyo, Japan & Jul-Aug 2003 & Megacity & $25-85$ & $\leq 1.5$ & SFOB & Sadanaga et al. (2004a) \\
\hline MILAGRO & Mexico City & Apr 2003 & Megacity & $10-200$ & - & & Shirley et al. (2006) \\
\hline PMTACS & New York, US & Jan-Feb 2004 & Megacity & $10-100$ & $\leq 1.5$ & SF & Ren et al. (2006a) \\
\hline- & Tokyo, Japan & Nov 2004 & Megacity & $10-100$ & $\sim 1$ & SFOB & Yoshino et al. (2006) \\
\hline- & Pennsylvania, US & May-Jun 2002 & Rural & $2-10$ & - & & Ren et al. (2005) \\
\hline PMTACS & $\begin{array}{l}\text { Whiteface- } \\
\text { Mountain, US }\end{array}$ & Jul-Aug 2002 & Rural, Forest & $4-10$ & $\sim 1$ & SFO & Ren et al. (2006b) \\
\hline- & $\begin{array}{l}\text { Brownsberg, } \\
\text { Suriname }\end{array}$ & Aug 2005 & $\begin{array}{l}\text { Tropics, } \\
\text { Rainforest }\end{array}$ & $53^{f}$ & $\sim 3$ & (g) & Sinha et al. (2008) \\
\hline OP-3 & $\begin{array}{l}\text { Borneo, } \\
\text { Malaysia }\end{array}$ & Apr-May 2008 & $\begin{array}{l}\text { Tropics, } \\
\text { Rainforest }\end{array}$ & $10-60$ & - & & Ingham et al. (2009) \\
\hline $\begin{array}{l}\text { PRIDE- } \\
\text { PRD2006 }\end{array}$ & PRD, China & Jul 2006 & $\begin{array}{l}\text { Subtropics, } \\
\text { Rural }\end{array}$ & $10-120$ & $\sim 2$ & S & This Work \\
\hline
\end{tabular}

a Range of measured data. Measurements are ground-based unless otherwise noted.

${ }^{\mathrm{b}}$ Missing reactivity (MR) expressed by the ratio $k_{\mathrm{OH}} / k_{\mathrm{OH}}^{\mathrm{calc}}$.

c Measured species that have been used to calculate $k_{\mathrm{OH}}^{\text {calc }}$. Abbr:: $\mathrm{S}=$ inorganic compounds $\left(\mathrm{O}_{3}, \mathrm{CO}\right.$, $\mathrm{NO}_{\mathrm{x}}$, etc.) plus hydrocarbons (including isoprene); $\mathrm{F}=$ formaldehyde; $\mathrm{O}=$ OVOCs, other than formaldehyde; $\mathrm{B}=$ biogenic $\mathrm{VOCs}$, other than isoprene.

d Median \pm standard deviation.

e Measurements aboard an aircraft.

${ }^{\mathrm{f}}$ Average value of two hours of measurements.

$k_{\mathrm{OH}}^{\mathrm{calc}}$ from measured methane, isoprene and OVOCs.

production rates, a significant missing $\mathrm{OH}$ source was discovered, which sustained high levels of $\mathrm{OH}$ in the order of $10^{7}$ radicals per $\mathrm{cm}^{3}$ at conditions of low $\mathrm{NO}(<1 \mathrm{pbb})$ and high $\mathrm{OH}$ reactivities $\left(\sim 20 \mathrm{~s}^{-1}\right)$.

Finally, $k_{\mathrm{OH}}$ data can be used to test the capability of photochemistry models to simulate atmospheric $\mathrm{OH}$ loss rates. In this paper $\mathrm{OH}$ reactivities from the afore mentioned PRD field campaign are presented. Observed reactivities are compared to $k_{\mathrm{OH}}^{\mathrm{calc}}$ calculations from individual trace gas measurements and to simulated reactivities $k_{\mathrm{OH}}^{\mathrm{model}}$ from a photochemical box model. The paper presents the chemical speciation to reactants that contribute most to the $\mathrm{OH}$ loss rate at PRD and investigates, how well modelled, yet unmeasured secondary chemical products explain the missing reactivity observed during the campaign.

\section{Field site and campaign}

PRD is located in Southern China in Guandong province and represents one of the major industrialized regions in Asia, with more than 20 million inhabitants. PRD includes the megacities of Hong Kong, Shenzhen and Guangzhou, and many fast-developing medium and small sized cities that are linked by a dense traffic network (Zhang et al., 2008b). Owing to the fast growing economy and urbanization, air pollution has greatly increased in this region during the last decade (Richter et al., 2005; Shao et al., 2006; Tie et al., 2006; Chan and Yao, 2008; Zhang et al., 2007, 2008b,a). Within the "Program of Regional Integrated Experiments of Air Quality over the Pearl River Delta" the photochemistry field campaign PRIDE-PRD2006 was conducted in summer 2006, aiming to investigate gas-phase chemistry and aerosol processes in a rural environment near Guangzhou city (Zhang et al., 2010, in preparation). Measurements were 
Table 2. Atmospheric compounds used to calculate $k_{\mathrm{OH}}$ values.

\begin{tabular}{|c|c|c|c|c|}
\hline Compound & Technique & Volume Mixing Ratio ${ }^{a}$ & $k_{\mathrm{OH}}^{\mathrm{calc} \mathrm{b}}$ & $k_{\mathrm{OH}}^{\text {model }}$ \\
\hline $\mathrm{OH}$ & Laser induced fluorescence & $\leq 1 \mathrm{ppt}^{\mathrm{d}}$ & - & $+\mathrm{e}$ \\
\hline $\mathrm{O}_{3}$ & UV photometry & $<120 \mathrm{ppb}\left(<0.2 \mathrm{~s}^{-1}\right)$ & - & + \\
\hline NO & Chemiluminescence & $<30 \mathrm{ppb}\left(<5.6 \mathrm{~s}^{-1}\right)$ & + & + \\
\hline $\mathrm{NO}_{2}$ & Chemiluminescence & $<40 \mathrm{ppb}\left(<10 \mathrm{~s}^{-1}\right)$ & + & + \\
\hline HONO & LOPAP $^{f}$ & $<5 \mathrm{ppb}\left(<0.5 \mathrm{~s}^{-1}\right)$ & - & + \\
\hline $\mathrm{CO}$ & IR photometry & $<4 \mathrm{ppm}\left(<424 \mathrm{~s}^{-1}\right)$ & + & + \\
\hline $\mathrm{CH}_{4}$ & FTIR $^{g}$ & $2.1 \mathrm{ppm}\left(0.3 \mathrm{~s}^{-1}\right)^{\mathrm{h}, \mathrm{i}}$ & + & + \\
\hline $\mathrm{H}_{2}$ & estimated & $550 \mathrm{ppb}\left(0.1 \mathrm{~s}^{-1}\right)^{\mathrm{i}}$ & + & + \\
\hline $\mathrm{C}_{2} \mathrm{H}_{6}$ & Canister sample $-\mathrm{GC}^{\mathrm{k}}$ & $1.5 \mathrm{ppb}\left(0.01 \mathrm{~s}^{-1}\right)^{\mathrm{i}}$ & + & + \\
\hline $\mathrm{C}_{2} \mathrm{H}_{4}$ & Canister sample $-\mathrm{GC}^{\mathrm{k}}$ & $3 \mathrm{ppb}\left(0.6 \mathrm{~s}^{-1}\right)^{\mathrm{i}}$ & + & + \\
\hline $\mathrm{C}_{3}-\mathrm{C}_{12}$ VOCs & Online $-\mathrm{GC}^{\mathrm{k}}$ & - & + & + \\
\hline $\mathrm{SO}_{2}$ & UV fluorescence & $10 \mathrm{ppb}\left(0.22 \mathrm{~s}^{-1}\right)^{l}$ & - & - \\
\hline $\mathrm{H}_{2} \mathrm{O}_{2}$ & Derivatisation/HPLC ${ }^{\mathrm{m}}$ & $0.75 \mathrm{ppb}\left(0.03 \mathrm{~s}^{-1}\right)^{l}$ & - & - \\
\hline $\mathrm{CH}_{3} \mathrm{OOH}$ & Derivatisation/HPLC ${ }^{m}$ & $0.24 \mathrm{ppb}\left(0.04 \mathrm{~s}^{-1}\right)^{l}$ & - & - \\
\hline
\end{tabular}

a Numbers in paranthesis represent $\mathrm{OH}$ reactivities of the listed compounds at ambient conditions.

b Plus signs indicate the compounds included in $k_{\mathrm{OH}}^{\mathrm{calc}}$.

c Plus signs indicate the compounds used as model input for $k_{\mathrm{OH}}^{\mathrm{model}}$.

${ }^{\mathrm{d}}$ Hofzumahaus et al. (2009).

e Used as model input in model sensitivity runs as explained in the text.

${ }^{\mathrm{f}}$ Long-path absorption photometry.

$\mathrm{g}$ Fourier-transform infrared spectrometry.

${ }^{\mathrm{h}}$ Mean value (Pinhua Xie, personal communication).

${ }^{\mathrm{i}}$ Fixed value (see text).

${ }^{\mathrm{k}}$ Gas chromatography; see measured species in Table 3.

${ }^{1}$ Median value (Hua et al., 2008).

${ }^{\mathrm{m}}$ High performance liquid chromatography.

performed from 3 to 30 July 2006 at Backgarden $\left(23.5^{\circ} \mathrm{N}\right.$, $113.03^{\circ} \mathrm{E}$ ), a regional background site about $60 \mathrm{~km}$ northwest of Guangzhou. Backgarden is located near a water reservoir and is surrounded by farmland (peanuts, lichees, trees). It experienced little local emissions from traffic, but biomass burning was occasionally observed on nearby agricultural fields. Temperature and relative humidity were generally high, of $28-36^{\circ} \mathrm{C}$ and $60-90 \%$, respectively, as is expected for a subtropical region during the rainy season. Extended rain fall occurred during two periods under the influence of typhoon Bilis (15-18 July) and Kaemi (26-29 July). At the field site local wind speeds were generally low and had values mostly less than $2 \mathrm{~m} / \mathrm{s}$ (Fig. 1). Such low wind speeds are typical in the inland of PRD during summer season and favor accumulation of air pollution (Chan and Yao, 2008).

Measurement instruments were operated at Backgarden to characterize the local atmosphere with respect to its gas phase composition (Hua et al., 2008; Hofzumahaus et al., 2009) and aerosol abundance and properties (Liu et al., 2008a; Garland et al., 2008; Xiao et al., 2009; Li et al., 2010; Rose et al., 2010). Mixing ratios of VOCs, $\mathrm{CO}, \mathrm{SO}_{2}, \mathrm{O}_{3}$, $\mathrm{H}_{2} \mathrm{O}_{2}, \mathrm{NO}_{\mathrm{x}}$ and photolysis frequencies were measured at $10 \mathrm{~m}$ above the ground on top of a hotel building that was exclusively used by the measurement team. Additional mea- surements of radical concentrations of $\mathrm{OH}$ and $\mathrm{HO}_{2}$, atmospheric $\mathrm{OH}$ reactivities, mixing ratios of $\mathrm{HONO}$ and meteorological data were performed nearby at a height of $7 \mathrm{~m}$ on top of two stacked sea containers. Atmospheric chemical species considered in this work are listed in Table 2 and 3.

\section{Experimental}

\subsection{Measurement of $k_{\mathrm{OH}}$}

Total atmospheric $\mathrm{OH}$ reactivities were measured as the inverse chemical $\mathrm{OH}$ lifetimes by a newly developed instrument, which is based on a pump-probe concept similar to the one explored by Calpini et al. (1999) and developed for field measurement by Sadanaga et al. (2004b). Laser flash photolysis (LP) of ozone is used to produce $\mathrm{OH}$ in a sample of ambient air and laser-induced fluorescence (LIF) is applied to monitor the time dependent $\mathrm{OH}$ decay. A short description of the LP-LIF instrument is given below, while technical details will be reported elsewhere (Lou et al., manuscript in preparation).

For measurement, ambient air is sampled through an $8 \mathrm{~m}$ long inlet-line (Silcosteel@, $8 \mathrm{~mm}$ I.D.) and is passed through a laminar flow tube at a rate of $20 \mathrm{litre} / \mathrm{min}$ at 


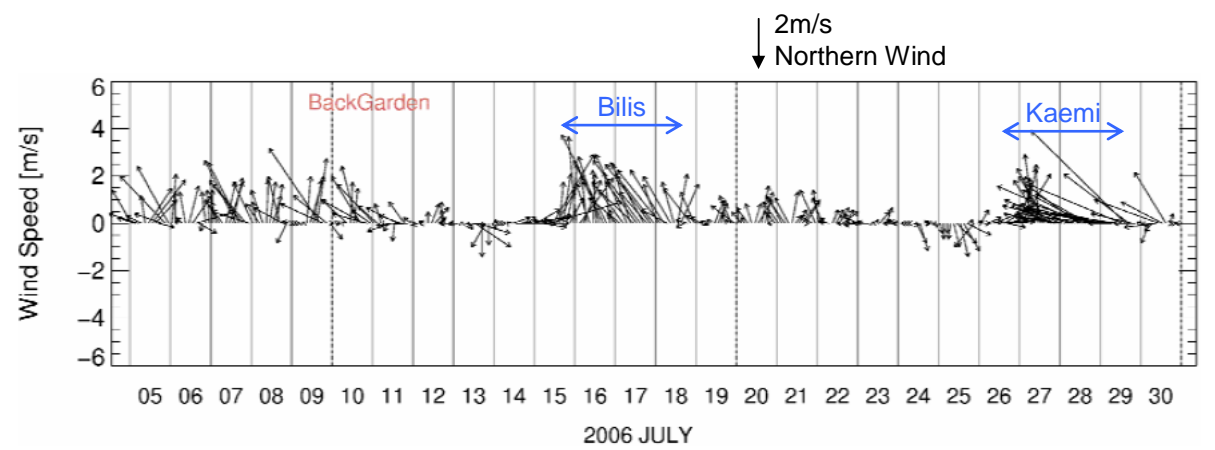

Fig. 1. Wind speed and direction at the Backgarden field site from 5 to 30 July. The ordinate scale refers to the north-south component of wind speed. The orientation of the black arrows denotes wind direction and the arrow length represents total wind speed. The horizontal blue double arrows show the time periods of typhoon Bilis and Kaemi.

Table 3. Volatile organic compounds measured by online GC.

\begin{tabular}{|c|c|}
\hline Class & Species \\
\hline Alkanes & $\begin{array}{l}\text { Propane, } n \text {-Butane, } i \text {-Butane, } n \text {-Pentane, } i \text {-Pentane, Cyclopentane, } n \text {-Hexane, } \\
\text { 2-Methylpentane, } 3 \text {-Methylpentane, } 2 \text {-2-Dimethylbutane, } 2 \text {,3-Dimethylbutane, } \\
\text { Cyclohexane, Methylcyclopentane, } n \text {-Heptane, } 2 \text {-Methylhexane, } 3 \text {-Methylhexane, } \\
\text { 2,3-Dimethylpentane, 2,4-Dimethylpentane, Methylcyclohexane, } n \text {-Octane, } \\
\text { 2-Methylheptane, 3-Methylheptane, } n \text {-Nonane, } n \text {-Decane, } n \text {-Undecane, } n \text {-Dodecane }\end{array}$ \\
\hline Alkenes & $\begin{array}{l}\text { Propene, 1-Butene, cis-2-Butene, trans-2-Butene, 1-Pentene, cis-2-Pentene, } \\
\text { trans-2-Pentene }\end{array}$ \\
\hline Dienes & Isoprene \\
\hline Aromatics & $\begin{array}{l}\text { Benzene, Toluene, Ethylbenzene, } n \text {-Propylbenzene, } i \text {-Propylbenzene, } \\
o \text {-Xylene, } m \text {-Xylene, } p \text {-Xylene, } o \text {-Ethyltoluene, } m \text {-Ethyltoluene, } p \text {-Ethyltoluene, } \\
\text { Styrene, } m \text {-Diethylbenzene, } p \text {-Diethylbenzene, } 1,2,3 \text {-Trimethylbenzene, } \\
\text { 1,2,4-Trimethylbenzene, } 1,3,5 \text {-Trimethylbenzene }\end{array}$ \\
\hline
\end{tabular}

atmospheric pressure. During the PRD campaign, the temperature of the sampling line and flow tube was kept at $40^{\circ} \mathrm{C}$, slightly above ambient temperature, to avoid possible condensation of water vapor in the instrument that was housed in an air-conditioned field container. The flow tube has a total length of $80 \mathrm{~cm}$ and an internal diameter of $40 \mathrm{~mm}$. A pulsed laser beam (266 nm, 10-20 mJ, FWHM 10 ns) from a frequency-quadrupled Nd-YAG laser (Big Sky, CFR200) is expanded to a diameter of $30 \mathrm{~mm}$ and is passed longitudinally through the centre of the flow tube, thereby generating $\mathrm{OH}$ radicals by flash photolysis of ozone (reactions $\mathrm{R} 1, \mathrm{R} 2)$. The initial $\mathrm{OH}$ concentration was always less than $5 \times 10^{9} \mathrm{~cm}^{-3}$ during the field campaign. The $\mathrm{OH}$ radicals react subsequently with the trace gases in the carrier flow on a time scale of tens to hundreds of milliseconds. About $50 \mathrm{~cm}$ downstream of the tube inlet, part of the air flow (3 litre/min) is diverted through an inlet nozzle into a low pressure cell for $\mathrm{OH}$ detection by LIF. The detection cell is essentially of the same type as for ambient $\mathrm{OH}$ radical measurement (Holland et al., 2003). The probe laser radiation $(308 \mathrm{~nm})$ comes from a tunable, frequency-doubled $8.5 \mathrm{kHz}$ pulsed dye laser (New Laser Generation, Tintura) which is shared between the $\mathrm{OH}$ reactivity instrument and the instrument for measurement of atmospheric $\mathrm{HO}_{\mathrm{x}}$ concentrations. With this setup, the timedependent chemical $\mathrm{OH}$ decay is probed by LIF while the flowing air passes through the tube along the inlet of the detection cell. The $\mathrm{OH}$ fluorescence signal is collected in a time-resolved mode by a multichannel scaler (Becker and Hickl, PM400A) and is stored in an array of time bins of $1 \mathrm{~ms}$ width over a time period of $2 \mathrm{~s}$. Decay curves are accumulated (signal-averaged) over successive photolysis pulses at a rate of $0.5 \mathrm{~Hz}$ to obtain a good signal-to-noise ratio. Examples of $\mathrm{OH}$ decay curves measured during the PRD field campaign 2006 are shown in Fig. 2. OH reactivities (reciprocal $\mathrm{OH}$ lifetimes) are obtained by non-linear least squares fits (CURVEFIT IDL-routine, Research Systems, Inc.) of the exponential decay curves. The precision of the derived $k_{\mathrm{OH}}$ values is between $4-10 \%(1 \sigma)$. The integration time for the $k_{\mathrm{OH}}$ measurements was typically 1-3 min.

In clean synthetic air (Messer Griesheim Austria, $99.999 \%)$ with admixed water vapor (1\%) and ozone (50 ppb, see below), zero decays resulting from $\mathrm{OH}$ wall loss were observed. At PRD, the zero decays had rate coefficients of $1.4 \pm 0.3 \mathrm{~s}^{-1}$, which were subtracted from the ambient air 


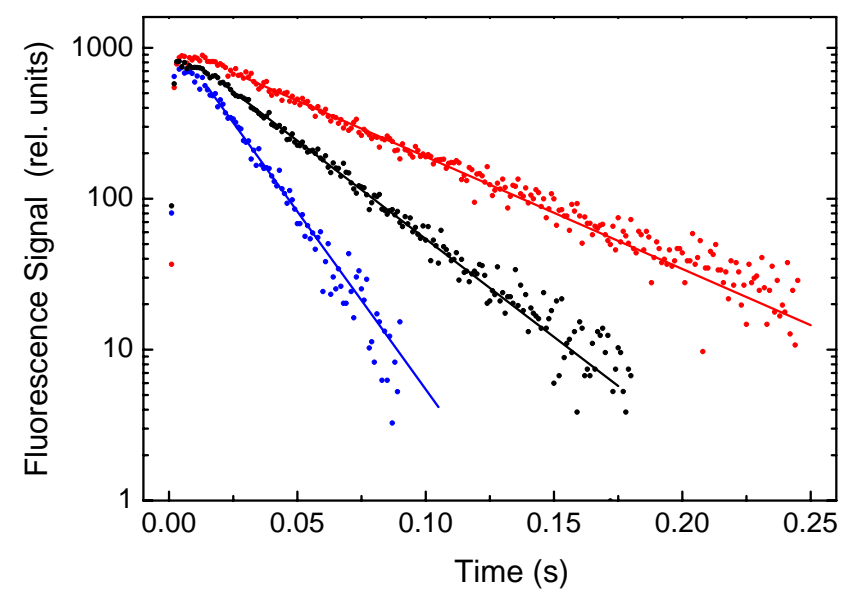

Fig. 2. OH decays measured in real-time by LP-LIF in different samples of air at the Backgarden field site in PRD on 11 July 2006. Dots denote the measured time-dependent fluorescence signals recorded in time bins of $1 \mathrm{~ms}$ width, after an off-resonance background signal (ca. 1 - 2 rel. units) has been subtracted. The solid lines are exponential fits to the decay curves, yielding $\mathrm{OH}$ reactivities as reciprocal 1/e liftetimes (red line $17 \mathrm{~s}^{-1}$; black line 30 $\mathrm{s}^{-1}$; blue line $54 \mathrm{~s}^{-1}$ ). The decay rate coefficients include the contribution of $\mathrm{OH}$ wall loss $\left(1.4 \mathrm{~s}^{-1}\right)$ in the flow tube, which needs to be subtracted to obtain atmospheric $\mathrm{OH}$ reactivities.

measurements. Gaseous components contributed very little to the zero decay rates, i.e. $0.05 \mathrm{~s}^{-1}$ came from analyzed contaminants (VOCs, $\mathrm{NO}_{\mathrm{x}}$ ), $0.1 \mathrm{~s}^{-1}$ from the added ozone and less than $0.04 \mathrm{~s}^{-1}$ from $\mathrm{OH}$ self-reaction $(\mathrm{OH}+\mathrm{OH})$. The corresponding total gas-phase reactivity $\left(<0.2 \mathrm{~s}^{-1}\right)$ was smaller than the uncertainty of the zero decay measurements and was neglected in the zero-decay correction of ambient air measurements.

Ozone from an ozone generator was added to the gas samples when they contained less than $10 \mathrm{ppb} \mathrm{O}_{3}$. This was the case during zero decay measurements and during air measurements at nighttime when ambient ozone dropped to low values. On these occasions, a controlled flow of $0.41 / \mathrm{min}$ of synthetic air was ozonized and mixed into the main flow $\left(20 \mathrm{l} / \mathrm{min}\right.$ ), resulting in a mixing ratio of about $50 \mathrm{ppb} \mathrm{O}_{3}$ entering the flow tube. The marginal dilution (2\%) of the main flow was corrected in the evaluation of the measured $\mathrm{OH}$ reactivities. The change of reactivity which may be caused by the reaction of air components with $\mathrm{O}_{3}$ was neglected, because the expected depletion of reactants (e.g., $\mathrm{NO}, \mathrm{NO}_{2}$, isoprene, or alkenes) by $\mathrm{O}_{3}$ is less than $0.1 \%$ over the measured lifetimes of $\mathrm{OH}$.

The accuracy of the instrument was tested before and after the campaign using air mixtures (e.g., $\mathrm{CO}$ in synthetic air) of known reactivities in the range of $0-190 \mathrm{~s}^{-1}$. The measurements were found to be linear for reactivities up to $60 \mathrm{~s}^{-1}$ and were accurate within 10\% (Hofzumahaus et al., 2009). At $k_{\mathrm{OH}}$ larger than $60 \mathrm{~s}^{-1}$, an increasing negative bias was noted in the measurement data, which was caused by the non-exponential curvature of the $\mathrm{OH}$ decay curves in the first $20 \mathrm{~ms}$ (Fig. 2). The deviations from the true reactivity were, for example, $-11 \%$ at $80 \mathrm{~s}^{-1}$ and $-18 \%$ at $100 \mathrm{~s}^{-1}$. This non-linearity affects less than $2 \%$ of the data points measured at PRD and was corrected using a parametrization based on results of the test measurements (Lou et al., manuscript in preparation). Note that the curvature responsible for the nonlinearity is independent of the chemical conditions. It partly comes from the rise of the $\mathrm{OH}$ fluorescence signal, when $\mathrm{OH}$ propagates initially into the LIF detection cell after the laser flash. Furthermore, the curvature may be influenced by nonhomogeneous spatial distribution of $\mathrm{OH}$ in the flow tube near the inlet nozzle which deflects some of the photolysis laser radiation.

Recycling of $\mathrm{HO}_{2}$ to $\mathrm{OH}$ (reaction R9) can slow down the observed $\mathrm{OH}$ decay in the reactor, if the reaction rate of $\mathrm{HO}_{2}$ and $\mathrm{NO}$ approaches the $\mathrm{OH}$ decay rate (Kovacs et al., 2003). This is generally the case after most $\mathrm{OH}$ has initially reacted with CO and VOCs, provided that sufficient NO is available. As a result, the observed $k_{\mathrm{OH}}$ becomes systematically smaller than the true $k_{\mathrm{OH}}$. The data correction for the NO dependent effect can be large in measurement systems that inject not only $\mathrm{OH}$ into the reactor, but also $\mathrm{HO}_{2}$. This is the case in flow-tube instruments with movable $\mathrm{OH}$ injectors which generate $\mathrm{OH}$ and $\mathrm{HO}_{2}$ as co-products by $185 \mathrm{~nm}$ photolysis of water vapor (Kovacs et al., 2003; Shirley et al., 2006; Ingham et al., 2009). For example, a correction factor of 1.4 at 5 ppb NO has been reported by Kovacs et al. (2003).

The LP-LIF technique is much less affected by NO since very little $\mathrm{HO}_{2}$ is initially generated. Sadanaga et al. (2004b) noted that $\mathrm{HO}_{2}$ which is produced by $266 \mathrm{~nm}$ laser photolysis of ambient formaldehyde ( $\mathrm{HCHO}$ ) can be neglected in their instrument. In our case, the estimated laser-generated $\mathrm{HO}_{2}$ concentration is $4 \times 10^{6} \mathrm{~cm}^{-3}$ at $20 \mathrm{ppb} \mathrm{HCHO}$ and $10 \mathrm{~mJ}$ laser energy. This radical concentration is an upper limit, as tropospheric $\mathrm{HCHO}$ mixing ratios were less than $20 \mathrm{ppb}$ at PRD (Sect. 6.2). Given an initial $\mathrm{HO}_{2} / \mathrm{OH}$ ratio in the order of $10^{-3}$ in our instrument, the conversion of laser generated $\mathrm{HO}_{2}$ to $\mathrm{OH}$ is negligible and only radical recycling following $\mathrm{OH}$ consumption (R3-R9) may become relevant. The error caused by recycling reaches at most $5 \%$ at $5 \mathrm{ppb}$ NO at PRD conditions. At higher NO (up to $30 \mathrm{ppb}$ ), biexponential behaviour of the $\mathrm{OH}$ decays became noticeable, which can be explained by radical recycling. In this case, a biexponential fit was applied to the measured $\mathrm{OH}$ decay curves. The faster of the two fitted decay rate coefficients was used as an estimator of the true $k_{\mathrm{OH}}$. The validity of this approximation was confirmed by numerical simulations and laboratory experiments, demonstrating that the error of this approach is less than 10\% for PRD conditions (Lou et al., manuscript in preparation).

The measurements in the flow tube were performed at an elevated fixed temperature, which was up to $12^{\circ} \mathrm{C}$ higher than ambient temperature. This caused a small negative bias 
in the measured $k_{\mathrm{OH}}$ for two reasons (cf., Eq. 2). First, the number densities of the reactants were reduced in the flow tube by $-0.3 \% \mathrm{~K}^{-1}$ according to the ideal gas law. Second, the $\mathrm{OH}$ rate coefficients of the major reactants (see Results and Discussion) have activation energies, which are either zero (e.g., $\mathrm{CO}, \mathrm{HCHO}$ ) or negative (e.g., $\mathrm{NO}, \mathrm{NO}_{2}$, alkenes, aromatics, other aldehydes). Considering the relative composition of measured and modelled species (cf. Sect. 4), the kinetic temperature dependence of $k_{\mathrm{OH}}$ is estimated to about $-0.2 \% \mathrm{~K}^{-1}$. Combining both temperature effects, the atmospheric reactivity is expected to be up to $6 \%$ larger than the $k_{\mathrm{OH}}$ measured at the experimental conditions during the campaign.

\subsection{Trace gas measurements}

$\mathrm{OH}$ concentrations were measured by LIF spectroscopy (Holland et al., 2003; Hofzumahaus et al., 2009). Ambient air was sampled by gas expansion into a low-pressure $(3.5 \mathrm{hPa})$ fluorescence cell, where the $\mathrm{OH}$ radicals were electronically excited by tunable, pulsed UV laser radiation at a wavelength of $308 \mathrm{~nm}$. The resulting $\mathrm{OH}$ resonance fluorescence was detected by time-delayed gated photon counting. The measurement system was calibrated using quantitative photolysis of water vapor in synthetic air at $185 \mathrm{~nm}$ as an $\mathrm{OH}$ source. For the PRD campaign, the limit of detection was $(0.5-1) \times 10^{6} \mathrm{~cm}^{-3}$ at 5 min integration time and the accuracy was $20 \%(1 \sigma)$.

$\mathrm{NO}_{\mathrm{x}}$ and $\mathrm{O}_{3}$ were measured by commercial instruments (Takegawa et al., 2006). NO was detected by $\mathrm{NO}^{-\mathrm{O}_{3}}$ chemiluminescence (Thermo Electron, Model 42CTL), while $\mathrm{NO}_{2}$ was first converted to NO in a photolytical reactor (Droplet Measurement Technologies, Model BLC). The instruments were calibrated using NO standard gas mixtures and gas phase titration for $\mathrm{NO}_{2}$. The 1-min detection limits for $\mathrm{NO}$ and $\mathrm{NO}_{2}$ were $50 \mathrm{pptv}$ and $170 \mathrm{pptv}$, respectively, and the corresponding accuracies were $7 \%$ and $13 \%$. Ozone was measured using an ultraviolet (UV) absorption instrument (Thermo Electron, Model 49C) with a $1 \sigma$ precision of $0.3 \mathrm{ppb}$ and an accuracy of $5 \%$.

$\mathrm{CO}$ measurements were obtained by a NDIR gas analyzer (Thermo Electron, Model 48C) with an integration time of 1 minute. Air samples were dried before measurement in order to avoid the interference from water vapour. The overall precision and accuracy were estimated to be $4 \mathrm{ppb}$ and $20 \mathrm{ppb}$, respectively, at a CO mixing ratio of $400 \mathrm{ppb}$.

HONO was measured by a commercial instrument (QUMA, Wuppertal) using the LOPAP technique developed by Kleffmann et al. (2006). The instrument had a detection limit of 7 pptv at a time resolution of $5 \mathrm{~min}$ and the accuracy of calibration was estimated to be $10 \%(1 \sigma)(\mathrm{X}$. Li, personal communication).

Measurements of alkanes, alkenes and aromatic compounds were performed using an automated gas chromatograph (Agilent, Model 6890 GC) equipped with dual columns and dual flame ionization detectors (Wang et al., 2008). Two sorbent traps were packed with different molecular sieves for a different range of VOCs. A porous-layer open tubular (PLOT) $\mathrm{Al}_{2} \mathrm{O}_{3} / \mathrm{KCl}$ column (Hewlett Packard) separated $\mathrm{C}_{3}-\mathrm{C}_{6}$ and a DB-1 column (J\&W) $\mathrm{C}_{6}-\mathrm{C}_{12}$. Calibration was performed by injecting various amounts of gas standard mixture containing the 51 target species with concentrations in the range between $3 \mathrm{ppb}$ and $15 \mathrm{ppb}$ (Spectra gas, Branchburg, NJ, USA). The accuracy for most of the measured VOCs estimated by comparing two traceable gas standards (68 $\mathrm{C}_{2}-\mathrm{C}_{11} \mathrm{NMHCs,} \mathrm{Scott} \mathrm{Marrin} \mathrm{Inc.;} 57 \mathrm{C}_{2}-$ $\mathrm{C}_{12}$ NMHCs, Spectra Gases Inc., USA) is within $10 \%$. The time resolution was one hour, the precisions mostly $1-3 \%$ and detection limits 6-70 pptv.

Photolysis frequencies were calculated from solar actinicflux spectra measured with a spectroradiometer (Meteorologie Consult) (Bohn et al., 2008). The radiometer was calibrated with a PTB-traceable irradiance standard before and after the campaign. The accuracy of derived photolysis frequencies is estimated to be about $10 \%$ at solar zenith angles smaller than $80^{\circ}$.

\section{Model calculations}

A zero-dimensional chemical model was used to calculate concentrations of radicals and photochemical products of nitrogen and carbon compounds. The underlying chemical mechanism (Karl et al., 2006) has been used before by Rohrer and Berresheim (2006) and Hofzumahaus et al. (2009). It is based on the Regional Atmospheric Chemical Mechanism (RACM) (Stockwell et al., 1997) which was upgraded with the isoprene degradation scheme by Karl et al. (2006). The latter scheme is a modified version (26 reactions) of the mechanism by Geiger et al. (2003), who prepared a condensed version of the Mainz Isoprene Mechanism (MIM, 44 reactions) (Pöschl et al., 2000). The isoprene chemistry by Karl et al. (2006) replaces directly the complete isoprene scheme of RACM and differs from the preceding mechanisms (Stockwell et al., 1997; Pöschl et al., 2000; Geiger et al., 2003) by treating MVK (methyl-vinyl ketone) and MACR (methacrolein) as separate species rather than lumping them in a single species. Furthermore, it introduces CAR4 as a substitute for the group of $\mathrm{C}_{4}$ and $\mathrm{C}_{5}$ hydroxy carbonyl compounds plus 3-methyl furane. The isoprene degradation scheme is fully documented by Karl et al. (2006) in Table 4 of their paper.

In this work, the model calculations were constrained to measurements of $\mathrm{O}_{3}, \mathrm{HONO}, \mathrm{NO}, \mathrm{NO}_{2}, \mathrm{CO}, \mathrm{CH}_{4}, \mathrm{C}_{3}-\mathrm{C}_{12}$ VOCs, photolysis frequencies, water vapor, ambient temperature and pressure (Table 2). Concentrations of ethane and ethene were set to fixed values of $1.5 \mathrm{ppb}$ and $3 \mathrm{ppb}$, respectively, estimated from a few canister samples. The $\mathrm{H}_{2}$ mixing ratio was assumed to be $550 \mathrm{ppb}$. The model was operated in a time-dependent mode with 5-min time resolution. First, 


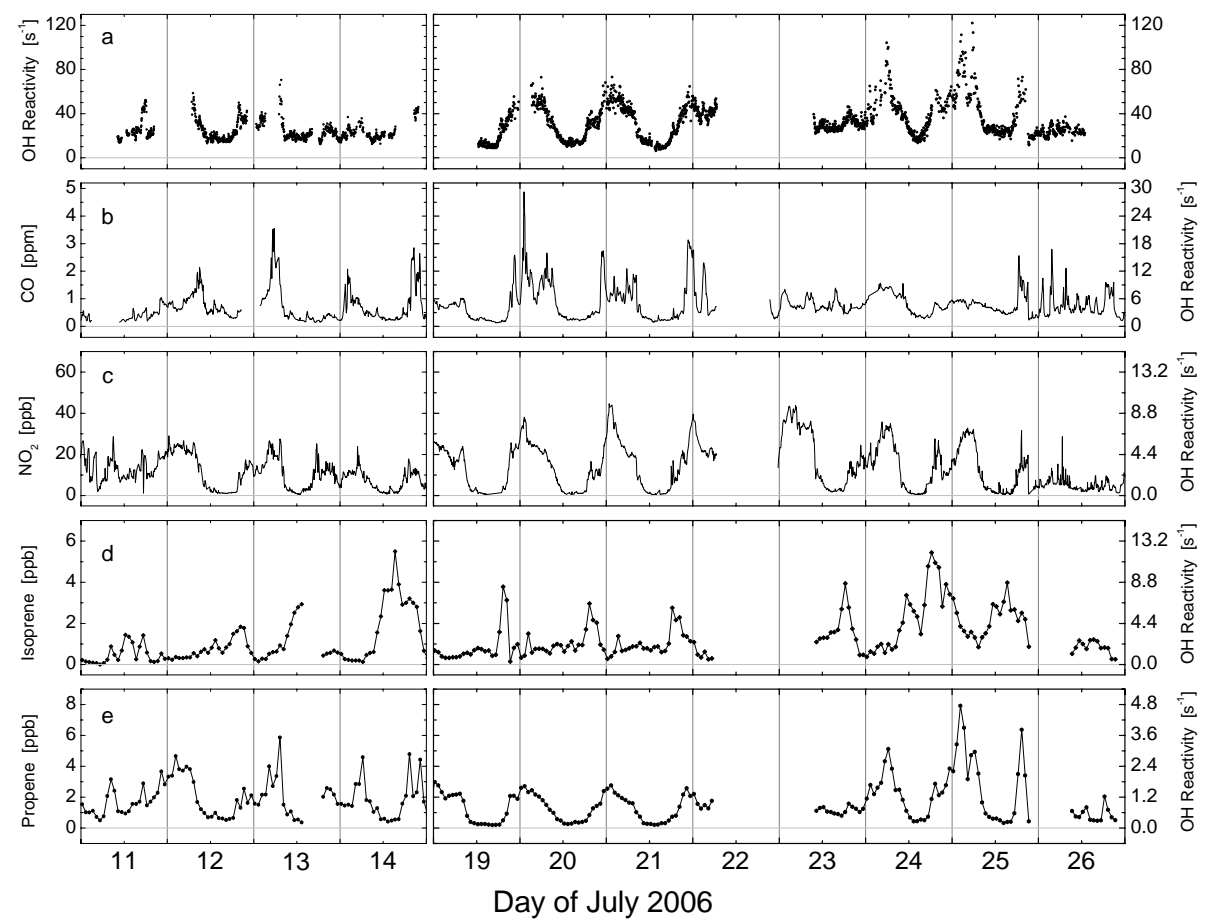

Fig. 3. Total $\mathrm{OH}$ reactivity (a) and volume mixing ratios of $\mathrm{CO}(\mathbf{b}), \mathrm{NO}_{2}$ (c), isoprene (d) and propene (e) measured at Backgarden site in PRD from 11 July to 26 July 2008. The right axis of panels (b)-(e) show corresponding reactivities of the individual trace gases. Data gaps at 15-18 July and 22 July were caused by heavy rain during the typhoon Bilis and an electrical power blackout, respectively. Vertical lines denote midnight.

a 5-min input dataset was generated by interpolation from measurements which had different time resolutions. During the model run, all measured input data were kept constant in each five minute interval and the calculated species concentrations were used as initial condition for the next 5-min time step. Each model run started with 2 days spin-up time to reach steady-state conditions for long-lived species. Additional loss by deposition with a corresponding lifetime of $24 \mathrm{~h}$ for calculated species was assumed to avoid build-up of unrealistic amounts of secondary products. Some additional model runs were performed as sensitivity studies. First, $\mathrm{OH}$ was constrained to match the observations. Second, the assumed value of the deposition lifetime for calculated species was varied. Details and results of the sensitivity runs are given below (Sect. 6.3).

\section{Results}

\subsection{Measurement results}

$k_{\mathrm{OH}}$ measurements are presented in Fig. 3 together with the measured concentrations of four selected trace gases $(\mathrm{CO}$, $\mathrm{NO}_{2}$, propene, isoprene) that react with $\mathrm{OH}$. The time series of $k_{\mathrm{OH}}$ has two major breaks which were caused by rainy weather conditions during typhoon Bilis on 15-18 July and an electrical power blackout at Backgarden on 22 July. The
$\mathrm{OH}$ reactivity data exhibit diurnal patterns which are most clearly pronounced during the sunny period from 19 to 25 July, with daily $k_{\mathrm{OH}}$ minima between $10 \mathrm{~s}^{-1}$ and $30 \mathrm{~s}^{-1}$ at noontime and peak values up to $120 \mathrm{~s}^{-1}$ at night. The temporal pattern is highly correlated with variations of anthropogenically emitted pollutants such as $\mathrm{CO}, \mathrm{NO}_{2}$ and propene (Fig. 3, lower panels). The pollutants accumulated in the shallow boundary layer at night and were depleted by photochemical degradation and vertical mixing within the rising boundary layer during daytime. Isoprene, which is emitted mostly by plants, behaved differently and reached maximum values in the late afternoon as expected from its temperature dependent emission rate. The observed isoprene (up to $5 \mathrm{ppb}$, equivalent to an $\mathrm{OH}$ reactivity of up to $12 \mathrm{~s}^{-1}$ ) made a significant contribution to $k_{\mathrm{OH}}$, but the variations of isoprene are not clearly discernible in $k_{\mathrm{OH}}$ which was dominated by the diurnal cycle of anthropogenic pollutants.

On two days (24-25 July) the $k_{\mathrm{OH}}$ data appear to be more scattered than on other days. The rather large short-term variability cannot be explained by instrumental noise, but was likely caused by local emissions in the surrounding neighborhood. Smoke plumes from small fires were observed on these days on agricultural fields nearby where harvest residues were burnt during daytime. During the nights of 23 24 and 24-25 July, a smell was noticeable that came presumably from waste combustion. The observation of combustion 

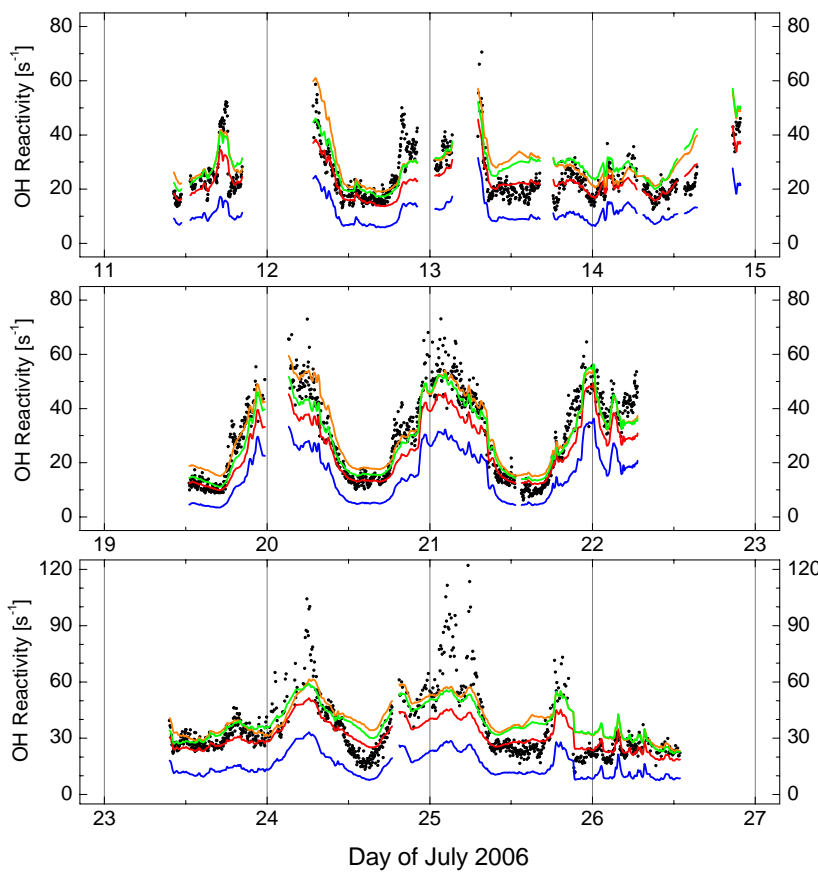

Fig. 4. Comparison of measured, calculated and modelled $k_{\mathrm{OH}}$ data at $1 \mathrm{~atm}$ and $313 \mathrm{~K}$. Dots: measured values. Blue line: $k_{\mathrm{OH}}^{\mathrm{calc}}$ values calculated from measured trace gases $\left(\mathrm{CO}, \mathrm{NO}_{\mathrm{x}}\right.$, hydrocarbons). Red line: model results, $k_{\mathrm{OH}}^{\text {model }}$ (RACM, base case). Green line: model results, $k_{\mathrm{OH}}^{\text {model }}$ (RACM, plus additional recycling by $\mathrm{X}$ ). Orange line: base case model using measured $\mathrm{OH}$ concentrations as an additional model constraint. Vertical lines denote midnight. Note the different $y$-axis scale in the lower panel.

coincides with a strong enhancement of measured aerosol mass concentration (factor 2-3 for PM1 and PM10) along with a change of aerosol optical properties which are indicative of smoldering fires (Garland et al., 2008). Finally, before midnight from 25 to $26 \mathrm{July}, k_{\mathrm{OH}}$ dropped sharply by a factor of 3 coinciding with the onset of rain. The rain fall in the wake of typhoon Kaemi continued throughout 26 July and the reactivity remained at $20 \mathrm{~s}^{-1}$.

In order to test how well the measured $k_{\mathrm{OH}}$ can be explained by the measured set of trace gases, $\mathrm{OH}$ reactivities were calculated according to Eq. (2) using the compounds listed in Table 2. The corresponding rate coefficients were taken from the RACM model and were applied for the instrumental conditions of the $k_{\mathrm{OH}}$ measurements ( $1 \mathrm{~atm}, 313 \mathrm{~K}$ ). The resulting $k_{\mathrm{OH}}^{\mathrm{calc}}$ data correlate well with the measurements, but are lower on average by a factor of 2 (Fig. 4). The discrepancy is even larger on 25 and 26 July and reaches a factor of 3-4 before sunrise, when the combustion smell was noticeable. In general, the differences between measured and calculated reactivities are significantly larger than the experimental error of $k_{\mathrm{OH}}(10 \%)$ and the estimated total uncertainty of $k_{\mathrm{OH}}^{\text {calc }}(20 \%)$, suggesting an additional missing reactivity.
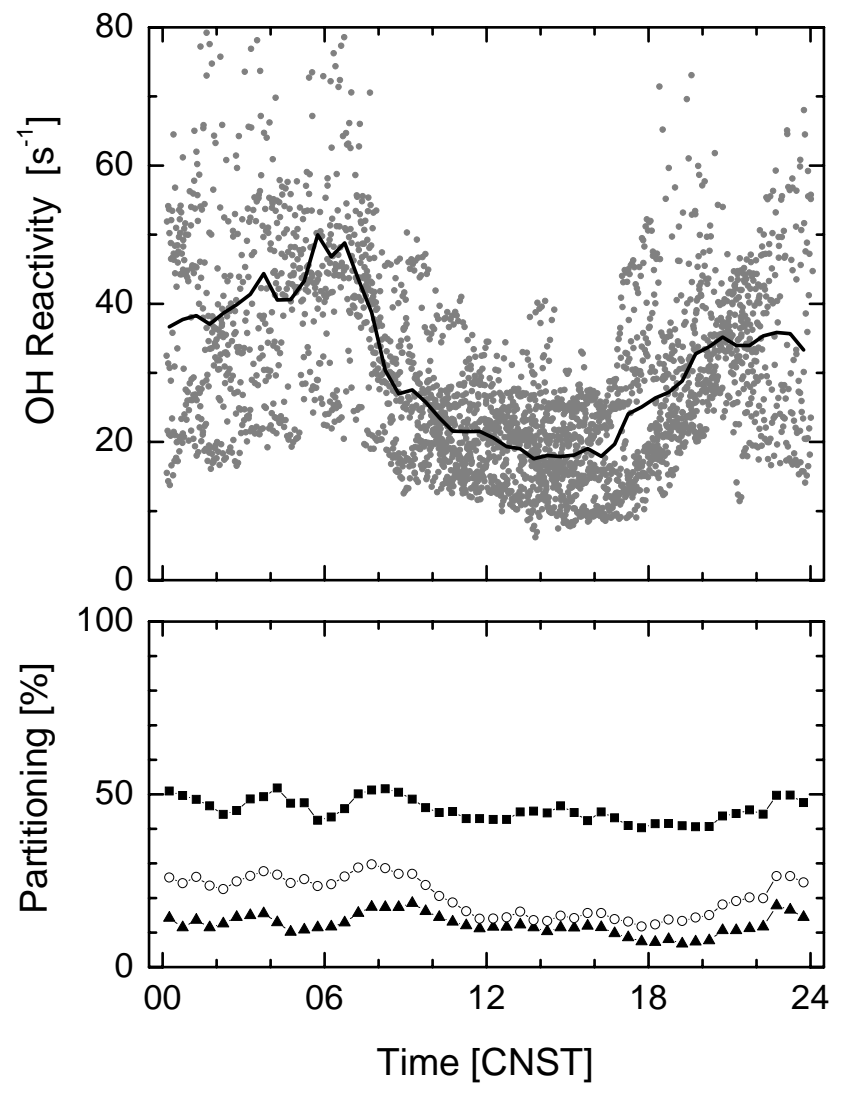

Fig. 5. Upper panel: diurnal variation of measured total $\mathrm{OH}$ reactivities at PRD for the days of 11-26 July 2006. Individual $k_{\mathrm{OH}}$ data are represented by gray dots and their half-hourly mean diurnal profile by the solid line. Lower panel: cumulative reactivities contributed by measured trace gases, normalized to the measured $k_{\mathrm{OH}}$ : $\mathrm{CO}$ (triangles), $\mathrm{CO}+\mathrm{NO}_{\mathrm{x}}$ (open circles), $\mathrm{CO}+\mathrm{NO}_{\mathrm{x}}+$ hydrocarbons (squares). The time of day is given in Chinese Standard Time $(\mathrm{CNST}=\mathrm{UTC}+8 \mathrm{~h})$, with solar noon at 12:30 CNST.

The measured $k_{\mathrm{OH}}$ data and their mean diurnal variation are displayed in Fig. 5 (upper panel) showing a minimum mean value of $20 \mathrm{~s}^{-1}$ at local noon and a maximum mean value of $50 \mathrm{~s}^{-1}$ at daybreak. The relative contributions of measured $\mathrm{CO}, \mathrm{NO}_{\mathrm{x}}$ and hydrocarbons are shown in the lower panel of Fig. 5. Interestingly, their cumulated contribution (black squared symbols) is nearly independent of time and explains half of the measured $\mathrm{OH}$ reactivity. The largest fraction of the explained reactivity comes from the group of measured VOCs which are further analyzed in Fig. 6. Here, the dominating speciated VOC reactivities are displayed versus time, normalized to the total reactivity of all measured hydrocarbons. Isoprene was seemingly the most important measured $\mathrm{OH}$ reactant during the daytime, with a contribution of up to $70 \%$ of the total hydrocarbon reactivity, whereas simple alkenes (propene, butenes, pentenes) and aromatic compounds (styrene, toluene, xylenes and trimethylbenzenes) were dominant at night. 


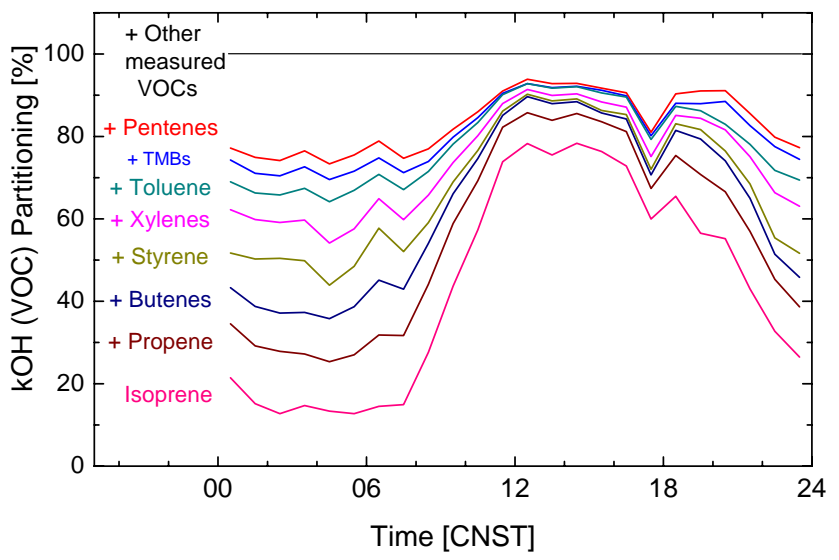

Fig. 6. Cumulative reactivities of measured hydrocarbons versus time of day, averaged for the days of 11-26 July 2006. The dominating VOC reactivities are displayed, normalized to the total reactivity of all measured hydrocarbons. The lowest (pink) line denotes isoprene, the next line (brown) denotes isoprene + propene, etc. Note: Butenes=1-butene, cis-2-butene, trans-2-butene; pentenes $=1$-pentene, cis-2-pentene, trans-2-pentene; xylenes $=o-$, $m$-, $p$-xylene; TMBs = 1,2,3-, 1,2,4-, 1,3,5-trimethylbenzene.

The question arises, which atmospheric components were responsible for the missing $50 \%$ of $\mathrm{OH}$ reactivity that is not explained by measured $\mathrm{CO}, \mathrm{NO}_{\mathrm{x}}$ and hydrocarbons? Other compounds that were measured $\left(\mathrm{O}_{3}, \mathrm{HONO}, \mathrm{SO}_{2}, \mathrm{H}_{2} \mathrm{O}_{2}\right.$ and $\mathrm{CH}_{3} \mathrm{OOH}$ ), but not included in $k_{\mathrm{OH}}^{\text {calc }}$, cannot explain the discrepancy, as their cumulated contribution is on average less than $1 \mathrm{~s}^{-1}$ and therefore negligible. The missing reactivity must be due to unmeasured primary reactants which were emitted by anthropogenic or biogenic sources directly, or to unmeasured secondary chemical species that have been formed photochemically in the atmosphere. These possibilities are discussed below.

\subsection{Model results}

In order to estimate the possible contribution of unmeasured secondary pollutants to the missing $\mathrm{OH}$ reactivity a photochemical box model was used (Sect. 4). Total OH reactivities $\left(k_{\mathrm{OH}}^{\text {model }}\right)$ were calculated from measured trace gases (Table 2) and all model-generated products, assuming instrumental conditions ( $1 \mathrm{~atm}, 313 \mathrm{~K}$ ) for the $\mathrm{OH}$ rate coefficients. The resulting model-derived reactivities are higher than $k_{\mathrm{OH}}^{\mathrm{calc}}$ by a factor of 1.4-2.6. They exhibit a similarly good correlation to measured $k_{\mathrm{OH}}$ as $k_{\mathrm{OH}}^{\text {calc }}$, but are in much better absolute agreement with the observations (Fig. 4). The model results agree well with the observed reactivities during daytime (except on 24 July, noon), but still underestimate the observations at night. The general trend can be seen more clearly in Fig. 7 (lower panel), where the mean diurnal profile of the modelled-to-measured $k_{\mathrm{OH}}$ ratio is displayed. From 08:00 to $17: 00$ the model and measurement results agree within $\pm 10 \%$. At night, however, the model underpredicts the measured reactivity systematically, with the largest discrepancy of $30 \%$ at sunrise.

\section{Discussion}

\subsection{Atmospheric $k_{\mathrm{OH}}$ variability}

The $\mathrm{OH}$ reactivities observed at Backgarden $\left(10-120 \mathrm{~s}^{-1}\right)$ are among the highest ever measured in field campaigns (Table 1). While clean air can have a reactivity as low as $\sim 1 \mathrm{~s}^{-1}$ in the remote marine boundary layer (Brauers et al., 2001 ), the highest $k_{\mathrm{OH}}$ values have been measured in polluted megacities with reported values of $10-200 \mathrm{~s}^{-1}$ in Mexico City (Shirley et al., 2006) and $10-100 \mathrm{~s}^{-1}$ in Tokyo (Sadanaga et al., 2005; Yoshino et al., 2006; Chatani et al., 2009) and New York City (Ren et al., 2003a, 2006a). Maximum values in Mexico City and New York City were observed during the morning and evening rush-hours, while minimum reactivities with mean values of $20-25 \mathrm{~s}^{-1}$ were measured in the afternoon at pollution levels of typically $20 \mathrm{ppb} \mathrm{NO}_{\mathrm{x}}$. High reactivities reaching about $60 \mathrm{~s}^{-1}$ were also observed in the tropical rainforest of Suriname (Sinha et al., 2008) and Borneo (Ingham et al., 2009), where natural emissions of isoprene and possible other biogenic VOCs dominated the $\mathrm{OH}$ reactivity.

The situation at the rural site in PRD is rather complex as it was strongly influenced by both anthropogenic and biogenic emissions. At night, the mean $\mathrm{OH}$ reactivity had values between $35 \mathrm{~s}^{-1}$ and $50 \mathrm{~s}^{-1}$ which were dominated by anthropogenic pollutants (Figs. 5 and 6). In the afternoon, the mean reactivity was about $20 \mathrm{~s}^{-1}$, which is similar to the observed values in New York and Mexico City. However, unlike in these cities, the afternoon values at PRD were biogenically influenced by several ppb of isoprene at relatively low $\mathrm{NO}_{\mathrm{x}}$ $(1-2 \mathrm{ppb})$. As mentioned above, about half of the observed reactivity at $\mathrm{PRD}$ can be explained by measured $\mathrm{CO}, \mathrm{NO}_{\mathrm{x}}$ and hydrocarbons, of which isoprene, light alkenes and aromatics make the largest contributions to the explained reactivity.

The high $\mathrm{CO}$ and $\mathrm{NO}_{\mathrm{x}}$ concentrations at night were probably caused by local combustion of coal for cooking and heating purposes, and presumably burning of waste and biomass. Furthermore, advected traffic emissions were strongly enhanced at night (Garland et al., 2008), as a result of local traffic regulations banning heavy Diesel trucks during daytime from 7:00 to 21:00 (Bradsher, 2007).

VOCs can have many sources in PRD (Liu et al., 2008b). The possible origin of light monoalkenes is from car traffic and biomass burning, and aromatic compounds may come from traffic exhaust, painting and industrial use of solvents. Isoprene is predominantly a biogenic tracer, but can also be a product of biomass burning and car exhausts (Liu et al., 2008b). 


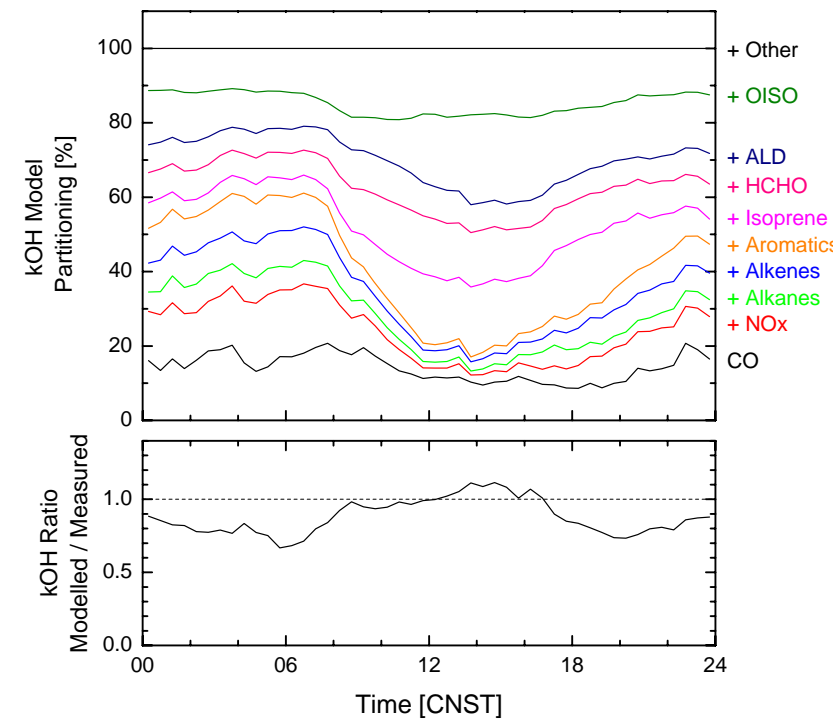

Fig. 7. Upper panel: cumulative $\mathrm{OH}$ reactivities of measured and modelled compounds normalized to the modelled, total $\mathrm{OH}$ reactivity. The data have been averaged for the days of $11-26$ July 2006. Note: $\mathrm{CO}, \mathrm{NO}_{\mathrm{x}}$, alkanes, alkenes, aromatics, and isoprene were used as model constraints (Table 2). HCHO, ALD, OISO and Other are products calculated by the RACM model (base case). 'Alkanes' include $\mathrm{H}_{2}$, methane and $\mathrm{C}_{2}-\mathrm{C}_{12}$ compounds; 'alkenes' include $\mathrm{C}_{2}-\mathrm{C}_{5}$ compounds; 'ALD' is the group of modelled acetaldehyde and higher aldehydes; 'OISO' is the group of modelled oxygenated isoprene products (MVK, MACR, CAR4, ISHP, etc.); 'Other' comprise all other model generated products like ketones, organic peroxides, nitrates, pernitrates, dicarbonyl compounds, etc. Lower panel: Ratio of the modelled to measured total $\mathrm{OH}$ reactivity.

\subsection{Missing reactivity}

The missing reactivity identified in Fig. 4 and 5 may come from unmeasured primary reactants emitted by anthropogenic or biogenic sources, or from unmeasured chemical species that were photochemically produced in the atmosphere. The good agreement between the modelled (base case) and measured reactivities during the time from 8:00 to 17:00 (Fig. 4 and Fig. 7, lower panel) suggests that photochemically formed products can explain the missing $\mathrm{OH}$ reactivity at daytime. The chemical partitioning of the modelled reactivity indicates that formaldehyde ( $\mathrm{HCHO}$ ), acetand higher aldehydes (ALD), and oxygenated isoprene products (OISO) are probably the most important $\mathrm{OH}$ reactants among the unmeasured, photochemical products (Fig. 7, upper panel). These oxidation products contribute $30-40 \%$ and other oxygenated compounds (ketones, dicarbonyl compounds, alcohols, hydroperoxides, nitrates etc.) 10-20\% of the total $\mathrm{OH}$ reactivity. Overall, organic species dominated $k_{\mathrm{OH}}$ and explain up to $85 \%$ (15:00 CNST) of the measured $\mathrm{OH}$ reactivity at daytime. It is noteworthy that isoprene $(17 \%)$ and its oxidation products OISO (24\%) played a prominent role in the afternoon, accounting for about $40 \%$ of the total reactivity.

The major modelled oxygenated VOCs (OVOCs) have mean daytime concentrations of about $12 \mathrm{ppb} \mathrm{HCHO}$, 3.8 ppb ALD, 1.1 ppb MVK, 0.6 ppb MACR, 0.9 ppb CAR4, and $0.44 \mathrm{ppb} \beta$-hydroxy hydroperoxide (ISHP, from isoprene). These compounds sum up to about $70 \%$ of the OVOC reactivity, while the remainder comes from small contributions of other model species. It is difficult to test the validity of the modelled concentrations rigorously, since in-situ measurements of OVOCs are missing, but the plausibility for some components can be checked. Formaldehyde, for example, may be compared to remote-sensing data that were measured during the field campaign by multi-axis differential optical absorption spectroscopy (MAX-DOAS). Assuming a well mixed atmospheric boundary layer, an average mixing ratio of $11 \pm 7 \mathrm{ppb} \mathrm{HCHO}$ was determined from differential slant column densities on 9 cloud-free days, with higher mixing ratios $(8-38 \mathrm{ppb})$ in the morning and lower values (3-12 ppb) in the afternoon (X. Li, personal communication). Ambient midday levels of aldehydes were also measured in PRD in summer 2003 by Feng et al. (2005), who observed mean values of $10 \mathrm{ppb} \mathrm{HCHO}$ and 5-6 ppb $\mathrm{CH}_{3} \mathrm{CHO}$ in downtown and semi-rural areas of Guangzhou. Our modelled aldehyde levels are of similar magnitude as the reported observations, though it must be noted that the modelled values have significant uncertainties (see Sect. 6.3). It can be further noted that the value of the modelled MVK+MACR to isoprene ratio (1.2) is in the range (1.1-1.4) that was measured during daytime by proton-transfer-reaction mass spectrometry (PTR-MS) in a rural area outside of Guangzhou in 2008 (M. Shao, personal communication). This comparison, however, is uncertain since the ratio of MVK+MACR to isoprene is variable (typically 0.4 to 2.4 ) depending on the photochemical age of the air mass (e.g., Karl et al., 2009; Shao et al., 2009).

A large contribution of aldehydes and other OVOCs to atmospheric reactivity was also reported in other studies in a variety of environments (Shao et al., 2009; Mao et al., 2010b; Steiner et al., 2008; Emmerson et al., 2007; Yoshino et al., 2006; Lewis et al., 2005). In Central California, US, Steiner et al. (2008) compared VOC reactivities from the regional Community Multiscale Air Quality model (CMAQ) with calculated reactivities for urban and agricultural measurement stations. In general, aldehydes and other OVOCs were found to contribute $30-50 \%$ of the modelled urban VOC reactivity (up to $30 \mathrm{~s}^{-1}$ ), while OVOCs accounted for up to $90 \%$ of the modelled reactivity in agricultural regions. In large cities (Houston, New York City, Mexico City), total $k_{\mathrm{OH}}$ was found to be dominated by anthropogenic hydrocarbons, $\mathrm{CO}$ and $\mathrm{NO}_{\mathrm{x}}$, while OVOCs contributed between 11-24\% during summertime (Mao et al., 2010b). In another urban study, Yoshino et al. (2006) analyzed $\mathrm{OH}$ reactivities measured in Tokyo at different seasons. In summer, measured hydrocarbons and OVOCs explained $26 \%$ and $14 \%$ of the 
total reactivity, respectively. A missing reactivity of $25 \%$ was ascribed to unmeasured OVOCs summing up to an estimated total OVOC fraction of 39\%. During the wintertime, hydrocarbons accounted for $25 \%$, OVOCs for $3-4 \%$, and unmeasured compounds for $5 \%$ of the total reactivity. These numbers indicate a much lower photochemical activity and lower OVOC production in winter (Yoshino et al., 2006). Detailed speciated measurements of VOCs and OVOCs were obtained during the summertime in Beijing by Shao et al. (2009), who analyzed the partitioning to the organic reactivity and its impact on photochemical ozone formation. The most abundant OVOCs were formaldehyde, acetaldehyde, acetone, methanol and ethanol, which contributed in total about $40 \%$ of the calculated organic reactivity. The measured diurnal pattern of acetaldehyde revealed that aldehydes were mostly photochemically formed (Shao et al., 2009). An essential role of OVOCs was also demonstrated in the TORCH campaign in south-east England in summer 2003, where aldehydes were not only an important sink of $\mathrm{OH}$, but also a significant photolytical source of $\mathrm{HO}_{\mathrm{x}}$ (Emmerson et al., 2007). Even in relatively clean environments, OVOCs have been found to play a significant role. Lewis et al. (2005) report observations of organic species at a remote observatory (Mace-Head) on the North-Atlantic coast of Ireland, where acetone, methanol and acetaldehyde contributed up to $80 \%$ of the calculated organic reactivity. Their data analysis demonstrates that a large fraction of OVOCs were formed by secondary chemistry in the background atmosphere. Airborne measurements of atmospheric reactants over the relatively clean Pacific Ocean have shown a contribution of about $20 \%$ of OVOCs to the loss rate of $\mathrm{OH}$ (Mao et al., 2009a). Direct $k_{\mathrm{OH}}$ measurements in the lower $2 \mathrm{~km}$, however, indicate a missing reactivity of more than a factor of 2, suggesting that some highly reactive VOCs had not been measured (Mao et al., 2009a).

In the present study, the box model underestimates systematically the measured $\mathrm{OH}$ reactivity at night and in the early morning by as much as $30 \%$ on average (Fig. 4 and 5). The discrepancies may be caused by systematic model errors (see below) or indicate unmeasured reactive emissions that are not captured by the model. Unknown emissions are the most likely cause of the large differences that occur during the nights of 24 and 25 July, when a combustion smell was clearly noticeable at the measurement site. As the burning material and the combustion conditions are not known, it is difficult to specify the emitted pollutants. A multitude of reactants can be emitted by combustion of organic materials, including various OVOCs, semivolatile organic compounds (SVOC), polyaromatic hydrocarbons (PAHs), halogen and nitrogen containing organic species (Andreae and Merlet, 2001; Lemieux et al., 2004), none of which were measured in this field study.

\subsection{Model uncertainty}

Given a missing reactivity of a factor 2 , it is surprising how well the RACM model reproduces the observed $\mathrm{OH}$ reactivity during the daytime (Fig. 7, lower panel). The model produces the right amount of OVOCs and other oxidation products to fill the gap between the calculated and measured reactivity. It is an interesting question, whether the good agreement during the daytime is just fortuitous and whether the systematic underestimation of $k_{\mathrm{OH}}$ by the model at night is significant?

The error of the model is at least as large as that of $k_{\mathrm{OH}}^{\mathrm{calc}}$ ( $\pm 20 \%$ ), which is determined by the measured air components and the corresponding rate constants. Additional uncertainty is caused by the reactivity of the modelled oxidation products. There are model uncertainties related to the loss and production of the calculated species. One source of error is the simplified treatment of the product loss by transport, assuming a fixed lifetime of $24 \mathrm{~h}$ for deposition of all calculated species in the model. This lifetime is equivalent to an assumed deposition velocity of $1.2 \mathrm{~cm} / \mathrm{s}$ and a boundary layer height of $1000 \mathrm{~m}$. The simplified treatment ignores the variability of the atmospheric boundary layer, wet deposition by rain events, and differences in the deposition velocities of different species. In order to test the sensitivity of $k_{\mathrm{OH}}^{\text {model }}$ to the assumed deposition lifetime, alternate lifetime values of $12 \mathrm{~h}$ and $48 \mathrm{~h}$ were used. The modified model yields time series of $k_{\mathrm{OH}}^{\text {model }}$ which look almost the same as for the base case (Fig. 8, lower panel). The oxidation product reactivities are 10-30\% different, causing only marginal differences (5-15\%) in the total $\mathrm{OH}$ reactivity. When the deposition loss is modulated by the diurnal variation of the boundary layer height (500-2000 m), derived from MAX-DOAS measurements (Li et al., 2010), similar small deviations from the base case result are found (not shown here). These tests demonstrate that the treatment of dry deposition loss in this work contributes only a relatively small error in $k_{\mathrm{OH}}^{\text {model }}$.

Another uncertainty is related to the inability of the model to reproduce afternoon $\mathrm{OH}$ concentrations which were measured together with $k_{\mathrm{OH}}$ at Backgarden. Hofzumahaus et al. (2009) found that the same model is capable of describing measured $\mathrm{OH}$ at $\mathrm{NO}>1 \mathrm{ppb}$ in the morning, but underestimates the observed $\mathrm{OH}$ concentration of $(1-2) \times 10^{7} \mathrm{~cm}^{-3}$ by a factor $3-5$ at NO levels of $0.1-0.2 \mathrm{ppb}$ in the afternoon. This shortcoming influences the predicted concentrations of secondary products which are produced by $\mathrm{OH}$ oxidation of VOCs. In order to test the influence of $\mathrm{OH}$ on $k_{\mathrm{OH}}^{\text {model }}$, additional sensitivity calculations were performed. The $\mathrm{OH}$ concentration was varied by a factor 2 , using twice and half of the modelled $\mathrm{OH}$ from the base run as model input for the sensitivity runs. The resulting time series of $k_{\mathrm{OH}}^{\text {model }}$ look again very similar to the base case (Fig. 8, upper panel). The relatively small sensitivity to $\mathrm{OH}$ variations can be explained by the fact that $\mathrm{OH}$ reactions are not only responsible for the 


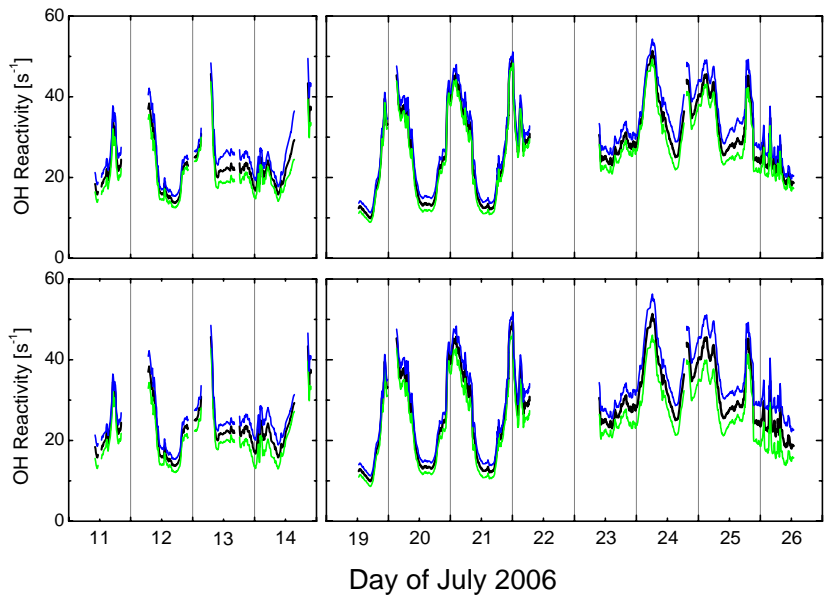

Fig. 8. Sensitivity test of modelled $\mathrm{OH}$ reactivities. Upper panel: variation of the $\mathrm{OH}$ concentration in the model runs. The black line represents the RACM model (base case) as shown in Fig. 4. The blue and green lines represent model results prescribing twice and half of the $\mathrm{OH}$ concentrations calculated in the base case run, respectively. Lower panel: variation of the deposition lifetime of modelled species. Black line: $24 \mathrm{~h}$ lifetime (base case); blue line: $48 \mathrm{~h}$ lifetime; green line: $12 \mathrm{~h}$ lifetime. Vertical lines denote midnight.

production of OVOCs, but also contribute to their chemical removal, which partly cancels the influence of $\mathrm{OH}$.

In order to be more realistic, the model was constrained to the measured $\mathrm{OH}$ concentrations in another test (Fig. 4, orange line). The modelled reactivity increases compared to the base case (Fig. 4, red line), improving the agreement with the measured nighttime reactivities. Daytime values of $k_{\mathrm{OH}}^{\text {model }}$ show relatively small changes on particular days (e.g. on 20, 21, 23 and 26 July) and remain in good agreement with the measurements. However, $k_{\mathrm{OH}}$ is considerably overpredicted by the model in the afternoon on several days, i.e. by a factor of 1.5 on 13, 14 and 25 July, and a factor of 2 on 24 July. It was discussed by Hofzumahaus et al. (2009) that a hypothetical additional primary source of $\mathrm{OH}$ could be introduced in the model to match the calculated to the much higher observed $\mathrm{OH}$ values in the afternoon. However, because the $\mathrm{OH}$ to $\mathrm{HO}_{2}$ ratio is largely maintained, this would also increase the modelled $\mathrm{HO}_{2}$ by a large factor meaning a strong overprediction of the observed $\mathrm{HO}_{2}$ concentrations. Likewise, OVOCs may be systematically overpredicted, if the model is constrained to measured $\mathrm{OH}$, only. In order to match both the observed $\mathrm{OH}$ and $\mathrm{HO}_{2}$, Hofzumahaus et al. (2009) proposed an additional radical recycling mechanism. Two hypothetical reactions with an unknown reactant $\mathrm{X}$ were introduced into the model, $\mathrm{RO}_{2}+\mathrm{X} \rightarrow \mathrm{HO}_{2}$ followed by $\mathrm{HO}_{2}+\mathrm{X} \rightarrow \mathrm{OH}$, both of similar rate as in case of the corresponding NO reactions. With this modification, the observed $\mathrm{OH}$ and $\mathrm{HO}_{2}$ concentrations could be well reproduced assuming a reactive equivalent of $0.85 \mathrm{ppb} \mathrm{NO}$ for
X (Hofzumahaus et al., 2009). If this mechanism is applied in the present work, the modelled reactivity becomes larger than in the base case, but mostly smaller than in the case when only measured $\mathrm{OH}$ is used as an additional constraint (Fig. 4). The model result (RACM, plus additional recycling by $\mathrm{X}$ ) is, with a few exceptions (see below), in general good agreement with the measured $k_{\mathrm{OH}}$. During daytime, the agreement is nearly as good as for the base case and during nighttime the agreement is much improved compared to the base case results.

The strong overprediction of $k_{\mathrm{OH}}$ in the afternoon of 13 , 14,24 and 25 July remains even if additional recycling by $\mathrm{X}$ is considered in the model. Given the relatively weak sensitivity of $k_{\mathrm{OH}}^{\text {model }}$ to ground deposition (see results above), it is unlikely that a specific error in deposition loss can explain the too large $k_{\mathrm{OH}}^{\text {model }}$ values on these particular days. In principle, heterogenous loss of OVOC species on particles (not included in the model) could have played a pronounced role on 24 and 25 July, when the atmospheric aerosol load was a factor of 2-3 higher than on the other days of the campaign (Garland et al., 2008). For example, unexpectedly low concentrations of gaseous glyoxal have been observed in urban air (Volkamer et al., 2007), consistent with reactive uptake onto particles reported from laboratory experiments (Liggio et al., 2005; Kroll et al., 2005). Glyoxal, however, contributes only about $2 \%$ of the total gas-phase reactivity in the present model. In order to compensate the overprediction of $k_{\mathrm{OH}}$ in the model, heterogeneous uptake would be required for formaldehyde, acetaldeyhde, MVK and MACR etc. which together contribute the major OVOC reactivity in the present work. These carbonyl compounds are known to have low physical solubilities in liquid water (Sander et al., 2006; Iraci et al., 1999). Reactive uptake might play a role for acidic solutions, but published results remain controversial for latter conditions (e.g., Noziere et al., 2006; Jang et al., 2005; Kroll et al., 2005). Since the enhanced aerosol load on 24 and 25 July contained a large fraction of soot in PRD (Garland et al., 2008), reactive uptake is not a likely explanation for the smaller than expected OVOC reactivity on these particular two days. It would also not explain the discrepancy between modelled and measured $k_{\mathrm{OH}}$ on the other two days (13-14 July), which did not exhibit elevated aerosol concentrations.

It is interesting that the four exceptional days $(13,14,24$ and 25 July) lay directly ahead of two typhoons and showed a meteorological situation that was different from all other days. During most of the campaign, wind came from the south and southeast at slow wind speeds (Fig. 1). On 1314 July and 24-25 July, local wind slowed down to almost zero and turned into opposite direction, coming then from the north. The four days exhibited the highest isoprene concentrations during the campaign, peaking in the afternoon at around 3-4 ppb (Fig. 3). The elevated isoprene concentrations and the very low wind speed point to the influence of a strong local isoprene source at close distance north of 


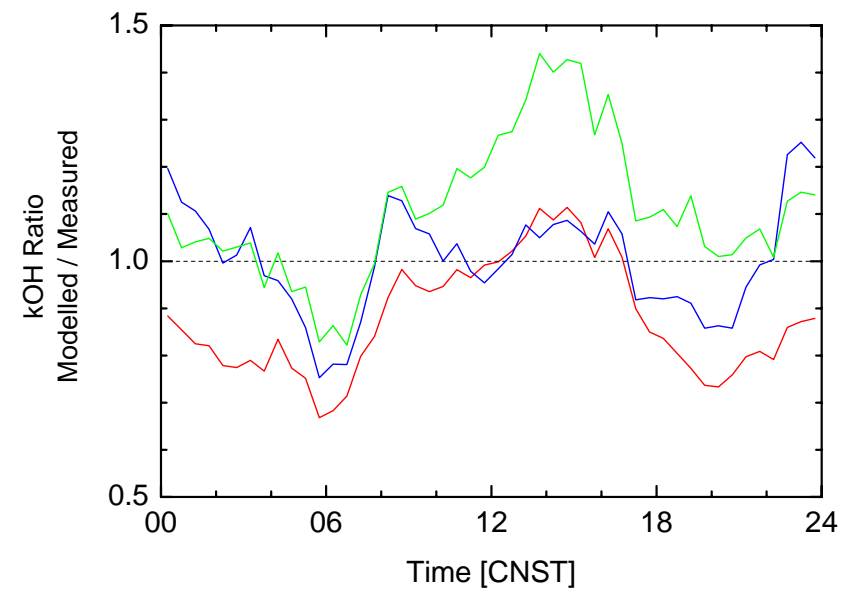

Fig. 9. Ratio of modelled to measured $k_{\mathrm{OH}}$ versus time of day. Red line: model base case. Green line: model plus additional radical recycling by $\mathrm{X}$, all days. Blue line: model plus additional radical recycling by $X$, days with northerly wind (13/14/24/25 July) excluded.

the field site. This is plausible, since there was an extended area with trees in the direct neighborhood north of the measurement building, whereas a drinking water reservoir with a fetch of about $1 \mathrm{~km}$ was located in the southern direction. It is likely that freshly emitted isoprene from the local source (north) was not significantly photochemically aged when it reached the sampling point of the $k_{\mathrm{OH}}$ instrument, but was mostly photochemically degraded downwind of the measurement site. The model, however, builds up isoprene oxidation products during daytime until the products reach steady state within few hours, a condition which was likely not fulfilled at the measurement site on 13-14 July and 24-25 July. In contrast, on the other days with continuously prevailing southern wind, primary VOCs were probably photochemically aged when they reached Backgarden, as implicitly assumed by the model.

Figure 9 summarizes the measurement model comparison showing mean diurnal profiles for the whole period of 11-26 July. $k_{\mathrm{OH}}^{\text {model }}$ increases on average by about $30 \%$ compared to the base case (red line), when additional radical recycling by $\mathrm{X}$ is included in the model (green line). This leads to good agreement with measured $k_{\mathrm{OH}}$ at night, but to a strong overprediction by a factor of 1.5 in the afternoon. When the data for northern wind direction (13-14 July and 24-25 July) are excluded, the overprediction during daytime is removed. The remaining deviations of the model from measured $k_{\mathrm{OH}}$ lie on average within $\pm 20 \%$ (blue line) which is not significant in view of the general model uncertainties discussed above.

\section{Conclusions}

Total atmospheric $\mathrm{OH}$ reactivities have been measured by a newly developed instrument at a rural site in the densely populated Pearl River Delta in Southern China in summer 2006. The deployed instrument uses laser flash photolysis of ozone to produce pulses of $\mathrm{OH}$ in samples of ambient air and applies laser-induced fluorescence to monitor the timedependent decay of laser-generated $\mathrm{OH}$. The experimental reactivities were derived as the inverse of chemical $\mathrm{OH}$ lifetimes with a total accuracy of about $10 \%$ at a time resolution of 1-3 min. In addition, a comprehensive set of atmospheric trace gases and meteorological parameters were measured.

The observed $\mathrm{OH}$ reactivities are among the highest ever reported by direct methods (Table 1), spanning a range from $10 \mathrm{~s}^{-1}$ to $120 \mathrm{~s}^{-1}$. On average, the reactivities exhibited a clear diurnal profile with a mean maximum value of $50 \mathrm{~s}^{-1}$ at daybreak and a mean minimum value of $20 \mathrm{~s}^{-1}$ at noon. The magnitude of these values and their diurnal variation is similar to what has been observed by other research groups in New York, Tokyo, or Mexico City, which are highly polluted, anthropogenically influenced locations. The measurement site in this study, however, was a green, rural site in the densely populated PRD. The $\mathrm{OH}$ reactivity was characterized by a background of anthropogenic pollutants at night and was dominated by local biogenic emissions of isoprene during the day.

The comparison of reactivities calculated from measured $\mathrm{CO}, \mathrm{NO}_{\mathrm{x}}$ and hydrocarbons with measured $k_{\mathrm{OH}}$ has revealed a missing reactivity of unmeasured species of about a factor of 2 at day and night. Box model calculations suggest that the missing reactivity is mainly contributed by OVOCs that were photochemically formed by oxidation of hydrocarbons. Despite the simplicity of the model, the agreement between measured and modelled $k_{\mathrm{OH}}$ is surprisingly good in view of the simplified model assumptions. The model reproduces the observed, time-dependent variability of $k_{\mathrm{OH}}$ and agrees within $10 \%$ at daytime, but underpredicts the measured nighttime values by $30 \%$. If the model is additionally constrained by the measured concentrations of $\mathrm{OH}$, agreement at night is improved, but daytime values become episodically overpredicted by as much as a factor of 2 . This overprediction is found only when the wind came from northern direction and the measurement site was influenced by local isoprene emissions which were probably not significantly photochemically degraded to OVOCs. If additional radical recycling is included in the model as postulated by Hofzumahaus et al. (2009) in order to explain both the observed $\mathrm{OH}$ and $\mathrm{HO}_{2}$ concentrations, the model calculates an $\mathrm{OH}$ reactivity that is in general good agreement with the measured $k_{\mathrm{OH}}$ when the prevailing wind came from southern directions. For the latter condition, the systematic differences between modelled and measured reactivities are in the range of $\pm 20 \%$ which is not significant in view of the general model uncertainties. 
Based on the measured trace gases and model calculated secondary products, $k_{\mathrm{OH}}$ was found to be dominated by VOCs and OVOCs, with a maximum total organic contribution of $85 \%$ in the afternoon. The major VOCs were light alkenes and aromatics at night and isoprene during day. According to the model, aldehydes and oxidized isoprene products were the dominating OVOC species, having a larger share of reactivity than the hydrocarbons during the daytime. The importance of OVOCs has also been recognized in other studies, which have analyzed atmospheric $\mathrm{OH}$ reactivities in marine, rural and urban air (see discussion above). In these environments, the OVOC reactivity was often of similar magnitude as that of hydrocarbons, if conditions were favoring photochemical oxidation of VOCs. This common result emphasizes the need for widespread OVOC measurements of high data quality, yet, at present, such measurements are not generally available on a routine basis (Apel et al., 2008). Improved measurement techniques for organic species and further measurements of atmospheric $\mathrm{OH}$ reactivities will be needed to make further progress in understanding tropospheric chemistry and its role in photochemical formation of ozone and aerosols.

Acknowledgements. We thank the PRiDe PRD2006 campaign team (2002CB410801), especially M. Hu, N. Takegawa, and A. Oebel for help and support at the field site. We thank Pinhua Xie, Anhui Institute of Optics and Fine Mechanics in Hefei, China, for providing the methane data. C. C. thanks Academic Sinica, Taiwan, for financial support of this work.

Edited by: A. Wiedensohler

\section{References}

Andreae, M. O. and Merlet, P.: Emission of trace gases and aerosols from biomass burning, Global Biogeochem. Cy., 15, 955-966, 2001.

Apel, E. C., Brauers, T., Koppmann, R., Bandowe, B., Boß meyer, J., Holzke, C., Tillmann, R., Wahner, A., Wegener, R., Brunner, A., Jocher, M., Ruuskanen, T., Spirig, C., Steigner, D., Steinbrecher, R., Alvarez, E. G., Müller, K., Burrows, J. P., Schade, G., Solomon, S. J., Ladstätter-Weißenmayer, A., Simmonds, P., Young, D., Hopkins, J. R., Lewis, A. C., Legreid, G., Reimann, S., Hansel, A., Wisthaler, A., Blake, R. S., Ellis, A. M., Monks, P. S., and Wyche, K. P.: Intercomparison of oxygenated volatile organic compound measurements at the SAPHIR atmosphere simulation chamber, J. Geophys. Res., 113, D20307, doi: 10.1029/2008JD009865, 2008.

Bohn, B., Corlett, G. K., Gillmann, M., Sanghavi, S., Stange, G., Tensing, E., Vrekoussis, M., Bloss, W. J., Clapp, L. J., Kortner, M., Dorn, H.-P., Monks, P. S., Platt, U., Plass-Dlmer, C., Mihalopoulos, N., Heard, D. E., Clemitshaw, K. C., Meixner, F. X., Prevot, A. S. H., and Schmitt, R.: Photolysis frequency measurement techniques: results of a comparison within the ACCENT project, Atmos. Chem. Phys., 8, 5373-5391, doi:10.5194/acp-85373-2008, 2008.
Bradsher, K.: Trucks Power China's Econonomy, at a Suffocating Cost, The New York Times - Online Edition, NY, USA, 8 December, 2007.

Brasseur, G. P., Prinn, R. G., and Pszenny, A. P. (eds.): Atmospheric Chemistry in a Changing World, The IGBP Series, Springer, Berlin, Germany, 2003.

Brauers, T., Hausmann, M., Bister, A., Kraus, A., and Dorn, H.P.: $\mathrm{OH}$ radicals in the boundary layer of the Atlantic Ocean 1. Measurements by long-path absorption spectroscopy, J. Geophys. Res., 106, 7399-7414, 2001.

Calpini, B., Jeanneret, F., Bourqui, M., Clappier, A., Vajtai, R., and van den Bergh, H.: Direct measurement of the total reaction rate of $\mathrm{OH}$ in the atmosphere, Analusis, 27, 328-336, 1999.

Chan, C. K. and Yao, X.: Air pollution in mega cities in China, Atmos. Environ., 42, 1-42, 2008.

Chatani, S., Shimo, N., Matsunaga, S., Kajii, Y., Kato, S., Nakashima, Y., Miyazaki, K., Ishii, K., and Ueno, H.: Sensitivity analyses of $\mathrm{OH}$ missing sinks over Tokyo metropolitan area in the summer of 2007, Atmos. Chem. Phys., 9, 8975-8986, doi:10.5194/acp-8-8975-2009, 2009.

Di Carlo, P., Brune, W. H., Martinez, M., Harder, H., Lesher, R., Ren, X., Thornberry, T., Carroll, M. A., Young, V., Shepson, P. B., Riemer, D., Apel, E., and Campbell, C.: Missing OH Reactivity in a Forest: Evidence for Unknown Reactive Biogenic VOCs, Science, 304, 722-724, 2004.

Ehhalt, D. H.: Photooxidation of trace gases in the troposphere, Phys. Chem. Chem. Phys., 1, 5401-5408, 1999.

Emmerson, K. M., Carslaw, N., Carslaw, D. C., Lee, J. D., McFiggans, G., Bloss, W. J., Gravestock, T., Heard, D. E., Hopkins, J., Ingham, T., Pilling, M. J., Smith, S. C., Jacob, M., and Monks, P. S.: Free radical modelling studies during the UK TORCH Campaign in Summer 2003, Atmos. Chem. Phys., 7, 167-1814, doi:10.5194/acp-7-167-2007, 2007.

Feng, Y., Wen, S., Chen, Y., Wang, X., Lü, H., Bi, X., Sheng, G., and Fu, J.: Ambient levels of carbonyl compounds and their sources in Guangzhou, China, Atmos. Environ., 39, 1789-1800, 2005.

Garland, R. M., Yang, H., Schmid, O., Rose, D., Nowak, A., Achtert, P., Wiedensohler, A., Takegawa, N., Kita, K., Miyazaki, Y., Kondo, Y., Hu, M., Shao, M., Zeng, L. M., Zhang, Y. H., Andreae, M. O., and Pöschl, U.: Aerosol optical properties in a rural environment near the mega-city Guangzhou, China: implications for regional air pollution, radiative forcing and remote sensing, Atmos. Chem. Phys., 8, 5161-5186, doi:10.5194/acp-85161-2008, 2008.

Geiger, H., Barnes, I., Bejan, I., Benter, T., and Spittler, M.: The tropospheric degradation of isoprene: an updated module for the regional atmospheric chemistry mechanism, Atmos. Environ., 37, 1503-1519, 2003.

Goldstein, A. H. and Galbally, I. E.: Known and Unexplored Organic Constituents in the Earth's Atmosphere, Environ. Sci. Technol., 41, 1514-1521, 2007.

Heald, C. L., Goldstein, A. H., Allan, J. D., Aiken, A. C., Apel, E., Atlas, E. L., Baker, A. K., Bates, T. S., Beyersdorf, A. J., Blake, D. R., Campos, T., Coe, H., Crounse, J. D., DeCarlo, P. F., de Gouw, J. A., Dunlea, E. J., Flocke, F. M., Fried, A., Goldan, P., Griffin, R. J., Herndon, S. C., Holloway, J. S., Holzinger, R., Jimenez, J. L., Junkermann, W., Kuster, W. C., Lewis, A. C., Meinardi, S., Millet, D. B., Onasch, T., Polidori, A., Quinn, 
P. K., Riemer, D. D., Roberts, J. M., Salcedo, D., Sive, B., Swanson, A. L., Talbot, R., Warneke, C., Weber, R. J., Weibring, P., Wennberg, P. O., Worsnop, D. R., Wittig, A. E., Zhang, R., Zheng, J., and Zheng, W.: Total observed organic carbon (TOOC) in the atmosphere: a synthesis of North American observations, Atmos. Chem. Phys., 8, 2007-2025, doi:10.5194/acp-82007-2008, 2008.

Hofzumahaus, A., Rohrer, F., Lu, K., Bohn, B., Brauers, T., Chang, C. C., Fuchs, H., Holland, F., Kita, K., Kondo, Y., Li, X., Lou, S., Shao, M., Zeng, L., Wahner, A., and Zhang, Y.: Amplified Trace Gas Removal in the Troposphere, Science, 324, 17021704, 2009.

Holland, F., Hofzumahaus, A., Schäfer, J., Kraus, A., and Pätz, H.W.: Measurements of $\mathrm{OH}$ and $\mathrm{HO}_{2}$ radical concentrations and photolysis frequencies during BERLIOZ, J. Geophys. Res., 108, 8246, doi:10.1029/2001, 2003.

Holzinger, R., Lee, A., Paw, K. T., and Goldstein, U. A. H.: Observations of oxidation products above a forest imply biogenic emissions of very reactive compounds, Atmos. Chem. Phys., 5, 67-75, doi:10.5194/acp-5-67-2005, 2005.

Hua, W., Chen, Z. M., Jie, C. Y., Kondo, Y., Hofzumahaus, A., Takegawa, N., Chang, C. C., Lu, K. D., Miyazaki, Y., Kita, K., Wang, H. L., Zhang, Y. H., and Hu, M.: Atmospheric hydrogen peroxide and organic hydroperoxides during PRIDE-PRD'06, China: their concentration, formation mechanism and contribution to secondary aerosols, Atmos. Chem. Phys., 8, 6755-6773, doi:10.5194/acp-8-6755-2008, 2008.

Ingham, T., Goddard, A., Whalley, L. K., Furneaux, K. L., Edwards, P. M., Seal, C. P., Self, D. E., Johnson, G. P., Read, K. A., Lee, J. D., and Heard, D. E.: A flow-tube based laser-induced fluorescence instrument to measure $\mathrm{OH}$ reactivity in the troposphere, Atmos. Meas. Techn., 2, 465-477, doi:10.5194/amt-2-465-2009, 2009.

Iraci, L. T., Baker, B. M., Tyndall, G. S., and Orlando, J. J.: Measurements of the Henry's law Coefficients of 2-Methyl-3-buten2-ol, Methacrolein, and Methylvinyl Ketone, J. Atmos. Chem., 33, 321-330, 1999.

Jang, M., Czoschke, N. M., and Northcross, A. L.: Semiempirical Model for Organic Aerosol Growth by Acid-Catalyzed Heterogeneous Reactions of Organic Carbonyls, Environ. Sci. Technol., 39, 164-174, 2005.

Karl, M., Dorn, H.-P., Holland, F., Koppmann, R., Poppe, D., Rupp, L., Schaub, A., and Wahner, A.: Product study of the reaction of $\mathrm{OH}$ radicals with isoprene in the atmosphere simulation chamber SAPHIR, J. Atmos. Chem., 55, 167-187, 2006.

Karl, T., Guenther, A., Turnipseed, A., Tyndall, G., Artaxo, P., and Martin, S.: Rapid formation of isoprene photo-oxidation products observed in Amazonia, Atmos. Chem. Phys., 9, 7753-7767, doi:10.5194/acp-9-7753-2009, 2009.

Kleffmann, J., Lörzer, J., Wiesen, P., Kern, C., Trick, S., Volkamer, R., Rodenas, M., and Wirtz, K.: Intercomparison of the DOAS and LOPAP techniques for the detection of nitrous acid (HONO), Atmos. Environ., 40, 3640-3652, 2006.

Kovacs, T. A. and Brune, W. H.: Total OH Loss Rate Measurement, J. Atmos. Chem., 39, 105-122, 2001.

Kovacs, T. A., Brune, W. H., Harder, H., Martinez, M., Simpas, J. B., Frost, G. J., Williams, E., Jobson, T., Stroud, C., Young, V., Fried, A., and Wert, B.: Direct measurement of urban OH reactivity during Nashville SOS in summer 1999, J. Environ. Mon- itor., 5, 68-74, 2003.

Kroll, J. H., Ng, N. L., Murphy, S. M., Varutbangkul, V., Flagan, R. C., and Seinfeld, J. H.: Chamber studies of secondary organic aerosol growth by reactive uptake of simple carbonyl compounds, J. Geophys. Res., 110, D23207, doi:10.1029/ 2005JD006004, 2005.

Lemieux, P. M., Lutes, C. C., and Santoianni, D. A.: Emissions of organic air toxics from open burning: a comprehensive review, Prog. Energ. Combust., 30, 1-32, 2004.

Lewis, A. C., Carslaw, N., Marriott, P. J., Klinghorn, R. M., Morrison, P., Lee, A. L., Bartle, K. D., and Pilling, M. J.: A larger pool of ozone-forming carbon compounds in urban atmospheres, Nature, 405, 778-781, 2000.

Lewis, A. C., Hopkins, J. R., Carpenter, L. J., Stanton, J., Read, K. A., and Pilling, M. J.: Sources and sinks of acetone, methanol, and acetaldehyde in North Atlantic marine air, Atmos. Chem. Phys., 5, 1963-1974, doi:10.5194/acp-5-1963-2005, 2005.

Li, X., Brauers, T., Shao, M., Garland, R. M., Wagner, T., Deutschmann, T., and Wahner, A.: MAX-DOAS measurements in southern China: retrieval of aerosol extinctions and validation using ground-based in-situ data, Atmos. Chem. Phys., 10, 20792089, doi:10.5194/acp-10-2079-2010, 2010.

Liggio, J., Li, S. M., and McLaren, R.: Reactive uptake of glyoxal by particulate matter, J. Geophys. Res., 110, D10304, doi:10. 1029/2004JD005113, 2005.

Liu, X., Cheng, Y., Zhang, Y., Jung, J., Sugimoto, N., Chang, S. Y., Kim, Y. J., Fan, S., and Zeng, L.: Influences of relative humidity and particle chemical composition on aerosol scattering properties during the 2006 PRD campaign, Atmos. Environ., 42, 15251536, 2008a.

Liu, Y., Shao, M., Fu, L., Lu, S., Zen, L., and Tang, D.: Source profiles of volatile organic compounds (VOCs) measured in China: Part I, Atmos. Environ., 42, 6247-6260, 2008b.

Mao, J., Ren, X., Brune, W. H., Olson, J. R., Crawford, J. H., Fried, A., Huey, L. G., Cohen, R. C., Heikes, B., Singh, H. B., Blake, D. R., Sachse, G. W., Diskin, G. S., Hall, S. R., and Shetter, R. E.: Airborne measurement of OH reactivity during INTEX-B, Atmos. Chem. Phys., 9, 163-173, doi:10.5194/acp-9-163-2009, 2009a.

Mao, J., Ren, X., Chen, S., Brune, W. H., Chen, Z., Martinez, M., Harder, H., Lefer, B., Rappenglück, B., Flynn, J., and Leuchner, M.: Atmospheric oxidation capacity in the summer of Houston 2006: Comparison with summer measurements in other metropolitan studies, Atmos. Environ., 44, 4107-4115, doi:10.1016/j.atmosenv.2009.01.013, 2010.

Martinez, M., Harder, H., Kovacs, T. A., Simpas, J. B., Bassis, J., Lesher, R., Brune, W. H., Frost, G. J., Williams, E. J., Stroud, C. A., Jobson, B. T., Roberts, J. M., Hall, S. R., Shetter, R. E., Wert, B., Fried, A., Alicke, B., Stutz, J., Young, V. L., White, A. B., and Zamora, R. J.: $\mathrm{OH}$ and $\mathrm{HO}_{2}$ concentrations, sources, and loss rates during the Southern Oxidants Study in Nashville, Tennessee, summer 1999, J. Geophys. Res., 108, 4617, doi:10. 1029/2003JD003551, 2003.

Matsumi, Y., Comes, F. J., Hancock, G., Hofzumahaus, A., Hynes, A. J., Kawasaki, M., and Ravishankara, A. R.: Quantum yields for production of $\mathrm{O}\left({ }^{1} \mathrm{D}\right)$ in the ultraviolet photolysis of ozone: Recommendation based on evaluation of laboratory data, J. Geophys. Res., 107, 4204, doi:10.1029/2001JD000 510, 2002.

McKeen, S. A., Mount, G., Eisele, F., Williams, E., Harder, J., 
Goldan, P., Kuster, W., Liu, S. C., Baumann, K., Tanner, D., Fried, A., Sewell, S., Cantrell, C., and Shetter, R.: Photochemical modeling of hydroxyl and its relationship to other species and during the Tropospheric $\mathrm{OH}$ Photochemistry Experiment, J. Geophys. Res., 102, 6467-6493, 1997.

Noziere, B., Voisin, D., Longfellow, C. A., Friedli, H., Henry, B. E., and Hanson, D. R.: The Uptake of Methyl Vinyl Ketone, Methacrolein, and 2-Methyl-3-butene-2-ol onto Sulfuric Acid Solutions, J. Phys. Chem. A, 110, 2387-2395, 2006.

Poppe, D., Bauer, R., Brauers, T., Brüning, D., Callies, J., Dorn, H.-P., Hofzumahaus, A., Johnen, F. J., Khedim, A., Koppmann, R., London, H., Müller, K. P., Neuroth, R., Plass-Dülmer, C., Platt, U., Rohrer, F., Rudolph, J., Schmidt, U., Wallasch, M., and Ehhalt, D. H.: A comparison of measured $\mathrm{OH}$ concentrations with model calculations, J. Geophys. Res., 99, 16633-16642, 1994.

Pöschl, U., von Kuhlmann, R., Poisson, N., and Crutzen, P. J.: Development and Intercomparison of Condensed Isoprene Oxidation Mechanisms for Global Atmospheric Modeling, J. Atmos. Chem., 37, 29-52, 2000.

Ren, X., Harder, H., Martinez, M., Lesher, R. L., Oliger, A., Shirley, T., Adams, J., Simpas, J. B., and Brune, W. H.: $\mathrm{HO}_{x}$ concentrations and $\mathrm{OH}$ reactivity observations in New York City during PMTACS-NY2001, Atmos. Environ., 37, 3627-3637, 2003a.

Ren, X., Harder, H., Martinez, M., Lesher, R. L., Oliger, A., Simpas, J. B., Brune, W. H., Schwab, J. J., Demerjian, K. L., He, Y., Zhou, X., and Gao, $\mathrm{H}$.: $\mathrm{OH}$ and $\mathrm{HO}_{2}$ Chemistry in the urban atmosphere of New York City, Atmos. Environ., 37, 3639-3651, 2003 b.

Ren, X., Brune, W. H., Cantrell, C. A., Edwards, G. D., Shirley, T., Metcalf, A. R., and Lesher, R. L.: Hydroxyl and Peroxy Radical Chemistry in a Rural Area of Central Pennsylvania: Observations and Model Comparisons, J. Atmos. Chem., 52, 231-257, 2005.

Ren, X., Brune, W. H., Mao, J., Mitchell, M. J., Lesher, R. L., Simpas, J. B., Metcalf, A. R., Schwab, J. J., Cai, C., Li, Y., Demerjian, K. L., Felton, H. D., Boynton, G., Adams, A., Perry, J., He, Y., Zhou, X., and Hou, J.: Behavior of $\mathrm{OH}$ and $\mathrm{HO}_{2}$ in the winter atmosphere in New York City, Atmos. Environ., 40, S252-S263, 2006a.

Ren, X., Brune, W. H., Oliger, A., Metcalf, A. R., Simpas, J. B., Shirley, T., Schwab, J. J., Bai, C., Roychowdhury, U., Li, Y., Cai, C., Demerjian, K. L., He, Y., Zhou, X., Gao, H., and Hou, J.: $\mathrm{OH}, \mathrm{HO}_{2}$, and $\mathrm{OH}$ reactivity during the PMTACS-NY Whiteface Mountain 2002 campaign: Observations and model comparison, J. Geophys. Res., 111, D10S03, doi:10.1029/2005JD006126, 2006b.

Richter, A., Burrows, J. P., Nüß, H., Granier, C., and Niemeier, U.: Increase of tropospheric nitrogen dioxide over China observed from space, Nature, 437, 129-132, 2005.

Rohrer, F. and Berresheim, H.: Strong correlation between levels of tropospheric hydroxyl radicals and solar ultraviolet radiation, Nature, 442, 184-187, 2006.

Rose, D., Nowak, A., Achtert, P., Wiedensohler, A., Hu, M., Shao, M., Zhang, Y., Andreae, M. O., and Pöschl, U.: Cloud condensation nuclei in polluted air and biomass burning smoke near the mega-city Guangzhou, China - Part 1: Size-resolved measurements and implications for the modeling of aerosol particle hy- groscopicity and CCN activity, Atmos. Chem. Phys., 10, 33653383, doi:10.5194/acp-10-3365-2010, 2010.

Sadanaga, Y., Yoshino, A., Kato, S., Yoshioka, A., Watanabe, K., Miyakawa, Y., Hayashi, I., Matsumoto, J., Nishiyama, A., Akiyama, N., Kanaya, Y., and Kajii, Y.: The importance of $\mathrm{NO}_{2}$ and volatile organic compounds in the urban air from the viewpoint of $\mathrm{OH}$ reactivity, Geophys. Res. Lett., 31, L08102, doi: 10.1029/2004GL019661, 2004a.

Sadanaga, Y., Yoshino, A., Watanabe, K., Yoshioka, A., Wakazano, Y., Kanaya, Y., and Kajii, Y.: Development of a measurement system of $\mathrm{OH}$ reactivity in the atmosphere by using a laserinduced pump and probe technique, Rev. Sci. Instrum., 75, 26482655, 2004b.

Sadanaga, Y., Yoshino, A., Kato, S., and Kajii, Y.: Measurements of $\mathrm{OH}$ Reactivity and Photochemical Ozone Production in the Urban Atmosphere, Environ. Sci. Technol., 39, 8847-8852, 2005.

Sander, S. P., Friedl, R. R., Golden, D. M., Kurylo, M. J., Moortgat, G. K., Keller-Rudek, H., Wine, P. H., Ravishankara, A. R., Kolb, C. E., Molina, M. J., Finlayson-Pitts, B. J., Huie, R. E., and Orkin, V. L.: Chemical Kinetics and Photochemical Data for Use in Atmospheric Studies, Evaluation Number 15, JPL Publ. 06-2, NASA-JPL, 2006.

Shao, M., Tan, X., Zhang, Y., and Li, W.: City clusters in China: air and surface water pollution, Front. Ecol. Environ., 4, 353-361, 2006.

Shao, M., Lu, S., Liu, Y., Xie, X., Chang, C., Huang, S., and Chen, Z.: Volatile organic compounds measured in summer in Beijing and their role in ground-level ozone formation, J. Geophys. Res., 114, D00G06, doi:10.1029/2008JD010863, 2009.

Shirley, T. R., Brune, W. H., Ren, X., Mao, J., Lesher, R., Cardenas, B., Volkamer, R., Molina, L. T., Molina, M. J., Lamb, B., Velasco, E., Jobson, T., and Alexander, M.: Atmospheric oxidation in the Mexico City Metropolian Area (MCMA) during April 2003, Atmos. Chem. Phys., 6, 2753-2765, doi:10.5194/acp-62753-2006, 2006.

Sinha, V., Williams, J., Crowley, J. N., and Lelieveld, J.: The Comparative Reactivity Method - a new tool to measure total $\mathrm{OH}$ Reactivity in ambient air, Atmos. Chem. Phys., 8, 2213-2227, doi:10.5194/acp-8-2213-2008, 2008.

Steiner, A. L., Cohen, R. C., Harley, R. A., Tonse, S., Millet, D. B., Schade, G. W., and Goldstein, A. H.: VOC reactivity in central California: comparing an air quality model to ground-based measurements, Atmos. Chem. Phys., 8, 351-368, doi:10.5194/acp-8351-2008, 2008.

Stockwell, W. R., Kirchner, F., Kuhn, M., and Seefeld, S.: A new mechanism for regional atmospheric chemistry modeling, J. Geophys. Res., 102, 25847-25879, 1997.

Takegawa, N., Miyakawa, T., Kondo, Y., Jimenez, J. L., Worsnop, D. R., and Fukuda, M.: Seasonal and diurnal variations of submicron organic aerosol in Tokyo observed using the Aerodyne Aerosol Mass Spectrometer, J. Geophys. Res., 111, D11206, doi: 10.1029/2005JD006515, 2006.

Tie, X., Brasseur, G. P., Zhao, C. S., Granier, C., Massie, S., Qin, Y., Wang, P. C., Wang, G., Yang, P. C., and Richter, A.: Chemical characterization of air pollution in Eastern China and the Eastern United States, Atmos. Environ., 40, 2607-2625, 2006.

Volkamer, R., San Martini, F., Molina, L. T., Salcedo, D., Jimenez, J. L., and Molina, M. J.: A missing sink for gas-phase glyoxal in Mexico City: Formation of secondary organic aerosols, Geo- 
phys. Res. Lett., 34, doi:10.1029/2007GL030752, 2007.

Wang, J. L., Wang, C. H., Lai, C. H., Chang, C. C., Liu, Y., Zhang, Y., Liu, S., and Shao, M.: Characterization of ozone precursors in the Pearl River Delta by time series observation of non-methane hydrocarbons, Atmos. Environ., 42, 6233-6246, 2008.

Xiao, R., Takegawa, N., Kondo, Y., Miyazaki, Y., Miyakawa, T., Hu, M., Shao, M., Zeng, L. M., Hofzumahaus, A., Holland, F., Lu, K., Sugimoto, N., Zhao, Y., and Zhang, Y. H.: Formation of submicron sulfate and organic aerosols in the outflow from the urban region of the Pearl River Delta in China, Atmos. Environ., 43, 3754-3763, 2009.

Yoshino, A., Sadanaga, Y., Watanabe, K., Kato, S., Miyakawa, Y., Matsumoto, J., and Kajii, Y.: Measurement of total $\mathrm{OH}$ reactivity by laser-induced pump and probe technique - comprehensive observations in the urban atmosphere of Tokyo, Atmos. Environ., 40, 7869-7881, 2006.

Zhang, J., Wang, T., Chameides, W. L., Cardelino, C., Kwok, J., Blake, D. R., Ding, A., and So, K. L.: Ozone production and hydrocarbon reactivity in Hong Kong, Southern China, Atmos. Chem. Phys., 7, 557-573, doi:10.5194/acp-7-557-2007, 2007.
Zhang, Y. H., Hu, M., Shao, M., Brauers, T., Chang, C. C., Holland, A. H. F., Li, X., Lu, K., Kita, K., Kondo, Y., Nowak, A., Pöschl, U., Rohrer, F., Zeng, L., Wiedensohler, A., and Wahner, A.: Continuous efforts to investigate regional air pollution in the Pearl River Delta, China: PRiDe PRD2006 campaign, Atmos. Chem. Phys., in preparation, 2010.

Zhang, Y. H., Hu, M., Zhong, L. J., Cheng, Y. F., Zeng, L. M., Wang, X. S., Xiang, Y. R., Wang, J. L., Gao, D. F., Shao, M., Fan, S. J., and Liu, S. C.: Regional ozone pollution and observationbased approach for analyzing ozone-precursor relationship during the PRIDE-PRD2004 campaign, Atmos. Environ., 42, 62036218, 2008a.

Zhang, Y. H., Hu, M., Zhong, L. J., Wiedensohler, A., Liu, S. C., Andreae, M. O., Wang, W., and Fan, S. J.: Regional Integrated Exeriments on Air Quality over Pearl River Delta 2004 (PRIDEPRD2004): Overview, Atmos. Environ., 42, 6157-6173, $2008 \mathrm{~b}$. 